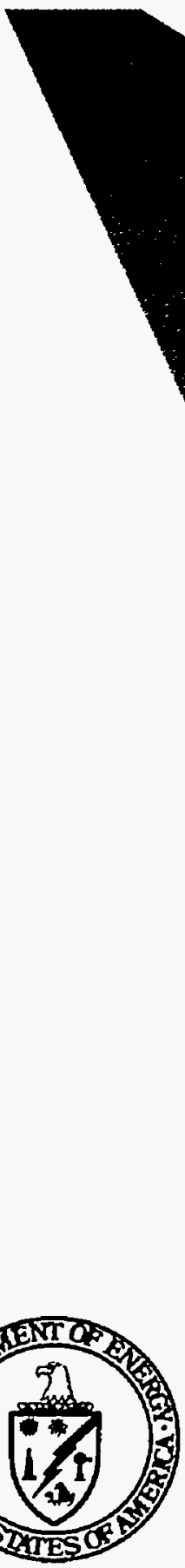

Worldwide Deposition of Strontium-90 through 1990 RECEIVED APR $2^{\text {y }}$ 1996

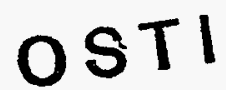

Matthew A. Monetti March 1996 


\title{
Worldwide Deposition of Strontium-90 through 1990
}

\author{
Matthew A. Monetti \\ Environmental Measurements Laboratory \\ U.S. Department of Energy \\ New York, NY 10014-3621
}

March 1996

\section{DISCLAIMER}

"This report was prepared as an account of work sponsored by an agency of the United States Government. Neither the United States Government nor any agency thereof, nor any of their employees, makes any warranty, express or implied, or assumes any legal liability or responsibility for the accuracy, completeness, or usefulness of any information, apparatus, product, or process disclosed, or represents that its use would not infringe privately owned rights. Reference herein to any specific commercial product, process, or service by trade name, trademark, manufacturer, or otherwise, does not necessarily constitute or imply its endorsement, recommendation, or favoring by the United States Government or any agency thereof. The views and opinions of authors expressed herein do not necessarily state or reflect those of the United States Government or any agency thereof."

This report has been reproduced directly from the best available copy.

Available from the National Technical Information Service, U. S. Department of Commerce, 5285 Port Royal Road, Springfield, Virginia 22161. 


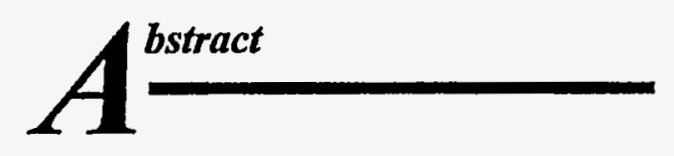

Strontium-90 results from the Environmental Measurements Laboratory's (EML) Global Fallout Program (GFP) are presented for the years 1987 through 1990 . Quarterly ${ }^{90} \mathrm{Sr}$ deposition results for the 66 sampling locations of EML's GFP were generally low, indicating that there was no significant release of fission products into the atmosphere during this period. The global ${ }^{90} \mathrm{Sr}$ deposition during these 4 years was lower than it has been for any similar period since this program began in 1958. Since there was no major atmospheric source of ${ }^{90} \mathrm{Sr}$ during this period, the global cumulative deposit of ${ }^{90} \mathrm{Sr}$ continued to decrease by radioactive decay to a 27 year low of $311.4 \mathrm{Pbq}$. 


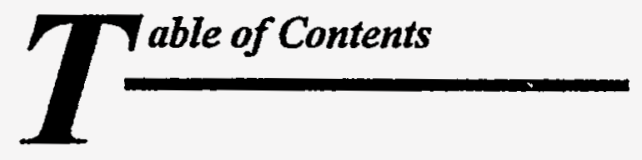

\section{Page No.}

Introduction $\quad \ldots \ldots \ldots \ldots \ldots \ldots \ldots \ldots \ldots \ldots \ldots \ldots \ldots \ldots \ldots \ldots \ldots \ldots \ldots \ldots \ldots \ldots$

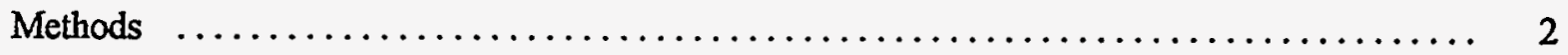

Data Quality and Validation $\quad \ldots \ldots \ldots \ldots \ldots \ldots \ldots \ldots \ldots \ldots \ldots \ldots \ldots \ldots \ldots \ldots \ldots \ldots$

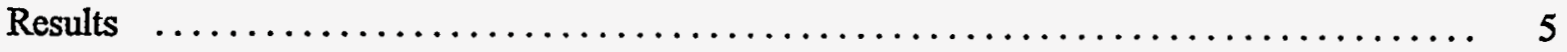

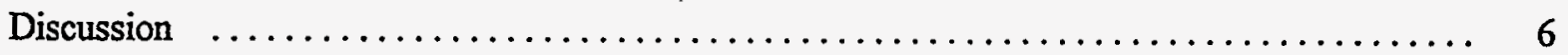

Acknowledgements $\ldots \ldots \ldots \ldots \ldots \ldots \ldots \ldots \ldots \ldots \ldots \ldots \ldots \ldots \ldots \ldots \ldots \ldots \ldots \ldots \ldots$

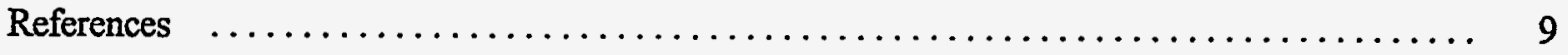

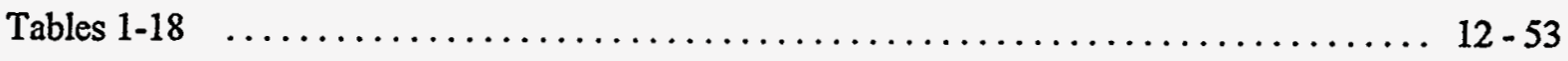






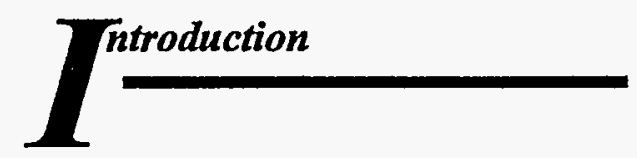

As a result of increased atmospheric testing of nuclear weapons, concerns over the fate of radioactivity released from these detonations and related implications to national security during the "arms race", the Environmental Measurements Laboratory (EML) initiated a program known as the Global Fallout Program (GFP) in 1958. This program has been operated via one of the largest global sampling networks ever assembled in the world. The GFP had over 140 sampling stations during the 1960s (Hardy, 1977). From 1987 to 1990, the network consisted of the 66 sites shown in Figure 1, and listed in Table 1 along with other site characteristics. The intent of the GFP was to obtain radionuclide deposition information which could be used to address factors related to the global transport and fate of radionuclides following an atmospheric release. Around the same time that this program was being developed several other global studies on fission-produced radioactivity were being pursued. These studies included investigations of atmospheric transport and residence times in both the stratosphere and the troposphere, soil burdens, and the subsequent assimilation into food and the human body. An essentially complete understanding of the processes affecting the fate of released radioactivity resulted, which helped to identify the significance of this material to human health.

Since it is considered important to maintain a record of the global deposition, distribution and inventory of fallout radioactivity, the GFP has remained an active program. Initially, GFP data included several of the radionuclides produced during weapons testing. Strontium-90 was chosen as the primary radionuclide of interest due to its unique properties. To begin with, ${ }^{90} \mathrm{Sr}$ is produced with a relatively high fission yield (3.7 PBq MCi per Megaton) during the detonation of nuclear weapons. Strontium-90 is also an beta-emitting radionuclide with a fairly long half-life (28 years). Finally, ${ }^{90} \mathrm{Sr}$ is readily incorporated into the biosphere as a result of chemical properties it shares with calcium, an essential element for most organisms including human. Together these properties have important implications on the effect that nuclear weapons fallout ${ }^{90} \mathrm{Sr}$ can have on human health. Strontium- 90 was considered the most important radionuclide released during the atmospheric weapons testing based on worldwide health hazards (UNSCEAR, 1982). EML's ${ }^{90} \mathrm{Sr}$ deposition database is the most extensive of its kind in the world. 
This report has been prepared to present additional new data that has been added to EML's database. Numerous documents similar to this one have been published regularly since the GFP began to provide the scientific community, policy-makers and the general public with information on radioactive fallout. Three compilation reports have been published to date (Hardy 1977; Larsen, 1984a; Larsen, 1985). The database now serves as a direct source of fallout records for contemporary investigations addressing radiological concerns. These records have also proven extremely useful for studies in several other fields that have utilized the unique and well-defined source of radioactivity as tracers of different processes.

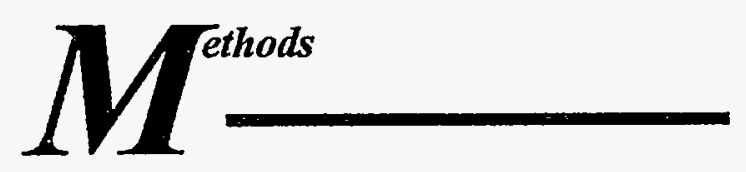

There have been very few changes in the procedures for the operation of the GFP since the years when the ${ }^{90} \mathrm{Sr}$ database was first generated. The same sampling devices are being used since the beginning of the program. These include two different open containers, a stainless-steel pot and a polyethylene bucket, and an ion-exchange unit (see Table 1). The open containers are simple devices that collect all the material which is deposited in them. The ion-exchange sampling unit performs a first-order extraction of the bulk deposition at the sampling site. It consist of a funnel connected in series to a column packed with Dowex-50 ion-exchange resin. The ion-exchange column removes the ${ }^{90} \mathrm{Sr}$ from the precipitation as it passes through the column. The sampling devices are exposed to collect a sample each calendar month, except for at the Australian stations where the samplers are exposed for a 3-month (quarterly) period. The area exposed to bulk deposition ranges from 640 to $760 \mathrm{~cm}^{2}$ depending on which device is used. The samplers and their operation are described in more detail in EML's Procedure Manual, Section 2 (Chieco et al., 1992).

The samples are sent to EML and prepared for analysis. The samples collected in pots and buckets are passed through ion-exchange columns in the laboratory. One column is used for each 3-month quarter of samples. The samples collected with the ion-exchange units are composted into quarterly samples by combining three months of samples. The ${ }^{90} \mathrm{Sr}$ analyses are then performed on quarterly samples (prior to 1976 the monthly samples were analyzed) by either EML or contractor laboratories. The radiochemical methods used to process, separate and count the samples for ${ }^{90} \mathrm{Sr}$ analysis are similar to those described in EML's Procedures Manual, Section 4 (Chieco et al., 1992). Blind quality control blanks and spiked 
reference samples are included with each set of samples and represent about $10 \%$ of the total samples analyzed. The contractors are required to meet specified criteria regarding agreement with quality control samples and counting errors for all samples.

Once the data is obtained it is evaluated for adherence to the contract specifications, converted to obtain values of ${ }^{90} \mathrm{Sr}$ deposition per unit area $\left(\mathrm{Bq} \mathrm{m}^{-2}\right)$, and added to the ${ }^{90} \mathrm{Sr}$ deposition database. The database is then used to update estimates of the total annual deposition and global burden of ${ }^{90} \mathrm{Sr}$. The method used to determine these values has been described by Volchok (1965). Representative ${ }^{90} \mathrm{Sr}$ deposition values $\left(\mathrm{Bq} \mathrm{m}^{-2}\right)$ are derived for each 10-degree latitude band based on the site data averages. Deposition values are obtained for the unsampled regions (north of $70^{\circ} \mathrm{N}$ and south of $70^{\circ} \mathrm{S}$ ) by extrapolating to a deposition of zero at the poles. The total ${ }^{90} \mathrm{Sr}$ deposition $(\mathrm{TBq})$ is calculated for each latitude band and then summed for a global total.

\section{$\int^{\text {ata Quality and Validation }}$}

As already mentioned, the contractors must meet established criteria to ensure that EML's database represents the best quality possible. Table 2 shows the results of blank samples submitted to four laboratories that performed analysis of samples collected from 1987 through 1990 . The laboratories are identified by letters to maintain anonymity. The number of results reported in Table 2 is proportional to the total number of samples analyzed by that particular laboratory. The mean blank values for each of the laboratories was below the established criteria set at $17 \mathrm{~Bq}$. One result reported by laboratory $\mathrm{A}$ and two results reported by laboratory $\mathrm{C}$ were above this limit, but the remainder of the results were generally well below this value. The blank result of $48.3 \pm 10.8 \mathrm{~Bq}$ was obtained due to difficulties encountered in processing a batch of samples. There is no apparent explanation for the other two high blank values.

Results of spiked reference samples are shown in Table 3. The contract specifies that the reported values must be within $20 \%$ of the known quantity added to the sample as suggested by Harley (1961) and Hardy (1973). All four of the laboratories had mean percent recovery values within this range, but again some individual analyses did not meet this criteria. Three, nine and three of the reported values analyzed by laboratory $A, C$ and $D$, respectively, were outside the contract limit. One of the values reported by 
laboratory $\mathrm{C}$ was in the same problem batch mentioned above. The apparent difficulty encountered with the analyses of four samples by laboratory $C$ and the three by laboratory $D$ involved ashing of the samples prior to transfer to the contractor. There is no obvious explanation for the remaining seven results that did not meet the established criteria.

Another set of criteria that was established to help ensure the high quality of ${ }^{90} \mathrm{Sr}$ data was limits for relative counting errors. The relative counting error limits set in the analytical contracts are as follows: $30 \%$ for results greater than 17 up through $34 \mathrm{~Bq} ; 15 \%$ for results greater than 34 up through $83 \mathrm{~Bq} ; 8 \%$ for results greater than 83 up through $167 \mathrm{~Bq}$; and $4 \%$ for results greater than $167 \mathrm{~Bq}$. No limit is defined for reported results of $17 \mathrm{~Bq}$ and lower since these values are anticipated to be at or below the detection limits. The superscript letters following the data in Table 4 indicate the relative counting errors. Few of the reported results exceeded the limits described above.

In addition to the criteria established to ensure the quality of the data, the database has been evaluated by direct comparisons with other programs. The United Kingdom Atomic Energy Authority (UKAEA) also had a global program to investigate the deposition of radioactivity. This program was also based on a global network similar in size to EML's GFP. The primary radionuclide of interest in the UKAEA program was ${ }^{137} \mathrm{Cs}$, but estimates of ${ }^{90} \mathrm{Sr}$ deposition were typically estimated by using a mean ${ }^{137} \mathrm{Cs}$ to ${ }^{90} \mathrm{Sr}$ ratio. Table 5 presents the UKAEA global ${ }^{90} \mathrm{Sr}$ deposition data from 1958 through 1990 (Playford et al., 1993), along with EML's GFP data. The largest difference between the annual ${ }^{90} \mathrm{Sr}$ deposition databases is $58 \%$ in 1970 , but overall the data are in good agreement. EML's annual ${ }^{90} \mathrm{Sr}$ deposition values are generally higher than the UKAEA values during the early period (1958 through 1992) of these programs, and the opposite is true during the later years. This comparison also indicates that EML's methodology is more sensitive than the UKAEA's for determining the global ${ }^{90} \mathrm{Sr}$ deposition since the UKAEA program could only report upper limit values from 1982 through 1990 . The cumulative ${ }^{90} \mathrm{Sr}$ deposit data shows even better agreement than the annual deposition. The largest coefficient of variation in the cumulative ${ }^{90} \mathrm{Sr}$ deposit is $6 \%$. It is likely that the differences between the two annual ${ }^{90} \mathrm{Sr}$ deposition databases can be accounted for as a result of varying meteorological conditions at the sampling locations between the networks (Hardy et al., 1968). Both programs calculate global averages values based on a few individual locations. Such an approach, although theoretically practical (Volchok, 1965), is certain to have some unknown error associated with it. The comparison between these two independent programs would indicate that this error is not great. 
Since the release of radionuclides during atmospheric weapons testing was well studied, other data is also available for comparison. Feely (1977) matched the GFP-derived estimates of ${ }^{90} \mathrm{Sr}$ deposition with ${ }^{90} \mathrm{Sr}$ deposition expected as a result of the net loss of ${ }^{90} \mathrm{Sr}$ in the stratosphere during 1974 to 1976. The GFP estimate was $18 \%$ higher than the stratospheric loss. This is a good agreement since both estimates are subject to uncertainties. Larsen (1984b) made a similar comparison with stratospheric ${ }^{90} \mathrm{Sr}$ data from 1976 through 1982. Again, the results indicate that there is good agreement between the loss of ${ }^{90} \mathrm{Sr}$ from the stratosphere and the global deposition values estimated by the GFP. These results indicate that the overall uncertainty of the annual estimates of global ${ }^{90} \mathrm{Sr}$ deposition may be as high as $20 \%$. This level of uncertainty would not significantly affect the interpretation or use of the GFP data.

\section{$\boldsymbol{R} \stackrel{\text { ests }}{-}$}

Quarterly ${ }^{90} \mathrm{Sr}$ deposition $\left(\mathrm{Bq} \mathrm{m} \mathrm{m}^{-2}\right.$ ) and precipitation $(\mathrm{cm})$ data from 1987 through 1990 are reported for the individual sampling locations shown in Table 4. The sites are listed in order of increasing distance from $90^{\circ} \mathrm{N}$ latitude. Annual totals of the quarterly results are provided in the last column of Table 4 .

Tables 6 to 9 list the average ${ }^{90} \mathrm{Sr}$ deposited $\left(\mathrm{Bq} \mathrm{m}{ }^{-2}\right)$ in each 10-degree latitude band and the entire world for the years 1987, 1988, 1989 and 1990, respectively. Averages are provided for each quarter along with an annual average. The number of sites used to calculate the average deposition are given next to the values. The letter " $E$ " indicates that no results were available to determine an average for the latitude band, so the average was calculated by extrapolation as mentioned in the Methods Section. The average deposition data is used to calculate the total ${ }^{90} \mathrm{Sr}$ deposits (TBq) in the latitude bands and the world shown in Tables 10 to 13 for the years 1987, 1988, 1989 and 1990, respectively. These tables present total deposition values for each quarter and a summation for the year. In Tables to 17, the total annual ${ }^{90} \mathrm{Sr}$ deposition is added to the previous global data to obtain the cumulative (decayed) burden of ${ }^{90} \mathrm{Sr}(\mathrm{PBq})$ in each latitude band and the world for the years 1987, 1988, 1989 and 1990, respectively. The data shows the cumulative deposit at the end of each quarter. Figure 2 is a histogram showing the latitudinal distribution of the global ${ }^{90} \mathrm{Sr}$ burden at the end of 1990 . The percent of the total global burden present in each 10-degree latitude band is also provided in this figure. 
The total annual ${ }^{90} \mathrm{Sr}$ deposition $(\mathrm{PBq})$ and fission yields of atmospheric weapons testing (MT) for the Northern and Southern Hemispheres are reported in Table 18. This table lists data from the inception of the GFP (1958) to the end of 1990. Figure 3 also displays some of the historical data available in the GFP. Figure 3A is a plot of the annual global ${ }^{90} \mathrm{Sr}$ deposition (PBq) from 1958 to 1990 . A graph of the annual fission yields from atmospheric weapons testing from 1945 to 1990 is shown in Figure 3B, and a graph of the cumulative global deposit of ${ }^{90} \mathrm{Sr}(\mathrm{PBq})$ from 1958 to 1990 is shown in Figure 3C. The value $(85.1 \mathrm{PBq})$ indicated in Figure $3 \mathrm{C}$ as the pre-1958 ${ }^{90} \mathrm{Sr}$ deposit was estimated from the fission yields of tests conducted prior to 1957 by assuming that each Megaton of nuclear explosive power generates 3.7 $\mathrm{PBq}$ of ${ }^{90} \mathrm{Sr}$.

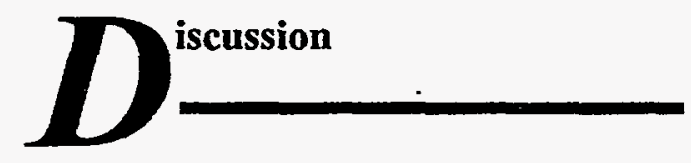

The bulk of the data in the GFP database has already been presented and interpreted in numerous reports over the years (e.g., Monetti and Larsen, 1991). As more data becomes available it is compared and appended to the historic database.

The site specific ${ }^{90} \mathrm{Sr}$ deposition data in Table 4 shows that the majority of the 1987 through 1990 values were low and indicate that there was no significant atmospheric source of ${ }^{90} \mathrm{Sr}$ on a global scale. This is in agreement with the fact that there were no announced atmospheric detonations or large-scale nuclear accidents. Also the presence of fission products in the surface air samples collected around the world was generally below the detection limit as noted in EML's Surface Air Sampling Program (Larsen and Sanderson, 1991). Thirty-seven percent of the quarterly ${ }^{90} \mathrm{Sr}$ deposition results reported in Table 4 had a value of zero, and another $37 \%$ of the data had a value below $0.1 \mathrm{~Bq} \mathrm{\textrm {m } ^ { - 2 }}$. The remaining $26 \%$ of the results generally were low values with high uncertainties. The ${ }^{90} \mathrm{Sr}$ deposition reported at these locations may simply have been due to the resuspension of previously deposited material. Some of the higher results are more interesting and require other explanations. Although the highest quarterly ${ }^{90} \mathrm{Sr}$ deposition, 7.4 $\mathrm{Bq} \mathrm{m}^{-2}$, was observed in the sample collected in Penu during the third quarter of 1989, this data is subject to high errors due to analytical difficulties. The next few locations in a series of decreasing quarterly ${ }^{90} \mathrm{Sr}$ deposition are all in Australia (Darwin during the fourth quarter of 1987, Townsville during the third quarter of 1989 and Perth during the fourth quarter of 1987 , with $6.2,2.1$ and $1.8 \mathrm{~Bq} \mathrm{~m}^{-2}$, 
respectively). The counting errors for these results were all low, but there were some unresolved problems with the quality control samples analyzed with several of the Australian samples. If there has been any atmospheric source of ${ }^{90} \mathrm{Sr}$ other than resuspension at any of the sampling stations during this period it would have been of limited quantity and extent. More detailed studies would be necessary to verify and identify potential radionuclide sources at specific locations of concern.

- The averaged ${ }^{90} \mathrm{Sr}$ deposition data reported in Tables 6 through 9 reflect the individual site data. The few elevated values resulted from the increased deposition at the individual locations noted above. There is no apparent temporal or spatial pattern to suggest that any event resulted in a global atmospheric release of radioactivity. The total ${ }^{90} \mathrm{Sr}$ deposited (Tables 10 to 13 ) during this period of time was insignificant relative to the burden of ${ }^{90} \mathrm{Sr}$ present at the time (Tables 14 to 17). The quantity of ${ }^{90} \mathrm{Sr}$ deposited from 1987 to 1990 was the lowest it is has been over any other 4-year period since the GFP began. Since the total ${ }^{90} \mathrm{Sr}$ deposition was less than the decay of the ${ }^{90} \mathrm{Sr}$ burden, the cumulative ${ }^{90} \mathrm{Sr}$ deposit decreased from 1987 to 1990 . At the end of 1990 , the global burden of ${ }^{90} \mathrm{Sr}(311.4 \mathrm{PBq})$ was lower than it has been in 27 years.

The bimodal latitudinal distribution of the global ${ }^{90} \mathrm{Sr}$ burden shown in Figure 2 is a result of factors controlling the transport of radioactivity released into the atmosphere. Atmospheric weapons tests injected most of the radioactivity into the stratosphere (Bennett, 1978). This material tended to remain in the stratosphere until the spring of the following year when it passed through the disruptions in the tropopause at midlatitudes in the Northern and Southern Hemispheres (UNSCEAR, 1982). Once in the troposphere, the material was carried around the world within Hadley cells. The fallout radionuclides were then deposited onto the earth's surface by both wet and dry deposition. This circulation pattern maintained latitudinal bands of peak radioactivity at the midlatitudes.

Nuclear weapons testing began in 1945, but the total fission yields produced were low until the early 1950 's (Figure 2B). Over 90\% of the weapons testing occurred in the Northern Hemisphere since 1958, but only $76 \%$ of the ${ }^{90} \mathrm{Sr}$ was deposited in the Northern Hemisphere (Table 18). Most of the ${ }^{90} \mathrm{Sr}$ deposited in the Southern Hemisphere was from Northern Hemisphere tests and was transported across the equator while it was in the stratosphere (Juzdan, 1988). Additionally, many of the tests conducted in the Northern Hemisphere were performed near the equator (Carter and Moghissi, 1977). The peak of weapons testing in 1962 resulted in the peak annual ${ }^{90} \mathrm{Sr}$ deposition in 1963 (Figure 2A). Another minor peak in the annual ${ }^{90} \mathrm{Sr}$ deposition database during 1959 followed the increased testing the year before. 
The cumulative ${ }^{90} \mathrm{Sr}$ deposit increased sharply during the early 1960 s because of the extensive testing conducted during this period. A moratorium on atmospheric weapons testing was observed since 1963 by all the countries involved except for China. Since this time, the fission yields have been low compared to the earlier testing yields. The annual global ${ }^{90} \mathrm{Sr}$ deposition sharply decreased as a result of the 1963 moratorium. The cumulative global ${ }^{90} \mathrm{Sr}$ deposit reached a maximum value (451.4 PBq) in 1966 and was maintained at this level for 6 years. Since 1972 the cumulative ${ }^{90} \mathrm{Sr}$ deposit has been decreasing since the radioactive decay of the global ${ }^{90} \mathrm{Sr}$ burden has been greater than the amount released into the atmosphere. The last atmospheric weapons test was performed by China at the Lop Nor test site on October 16, 1980 . Most of the ${ }^{90} \mathrm{Sr}$ associated with this test was deposited in 1981 . The ${ }^{90} \mathrm{Sr}$ deposited during 1986 was due to the Chernobyl accident in the Ukraine Republic of the former Soviet Union. Strontium-90 was distributed throughout the Northern Hemisphere, but the event was primarily of regional importance with greatest effects in Europe. The GFP was able to provide some interesting information on the transport and fate of this release (Monetti and Larsen, 1991). There was no significant global ${ }^{90} \mathrm{Sr}$ deposit from 1987 through 1990, and the cumulative deposit continued to decrease.

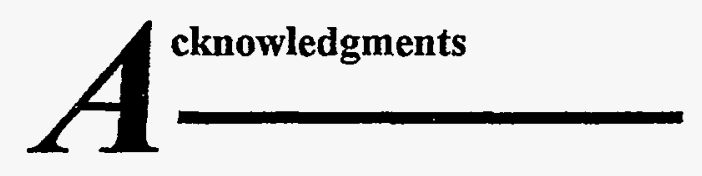

EML is extremely grateful for the support of the site operators who maintain the deposition sampling stations around the world. Their efforts are greatly appreciated but often not formally recognized. We would also like to thank all of those who aided us in establishing and maintaining the network. This includes those individuals or groups who served as contacts to ensure that supplies and information was relayed to the appropriate locations. This program could not have been accomplished without the assistance of all these people. 


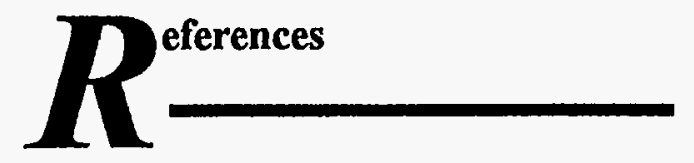

Bennett, B. G.

"Environmental Aspects of Americium"

USERDA Report EML-348, December (1978)

Carter, M. and A. Moghissi

"Three Decades of Nuclear Testing"

Health Physics, 33, 55-71, July (1977)

Chieco, N. A., D. C. Bogen and E. O. Knutson

"EML Procedures Manual"

HASL-300, 27th Edition, Vol. 1, November (1992)

Feely, H. W.

"Worldwide Deposition of ${ }^{90} \mathrm{Sr}$ through 1976 "

USERDA Report HASL-328, pp. 1-85-I-103, October (1977)

Hardy, E. P., Jr.

"Analysis of Quality Control Samples at HASL and a Contractor Laboratory - during 1972"

USERDA Report HASL-268, January (1973)

Hardy, E. P., Jr.

"Final Tabulation of Monthly ${ }^{\circ} \mathrm{Sr}$ Fallout Data, 1954-1976"

USERDA Report HASL-329, October (1977)

Hardy, E. P., Jr., M. W. Meyer, J. S. Allen and L. T. Alexander

"90-Sr on the Earth's Surface"

Nature, 219, 584-587 (1968) 
Harley, J. H.

"Errors in Measurement"

USAEC Report HASL-105, January (1961)

Juzdan, Z. R.

"Worldwide Deposition of ${ }^{90} \mathrm{Sr}$ through 1985"

USDOE Report EML-515, July (1988)

Larsen, R. J.

"Graphic Presentation of Quarterly ${ }^{90} \mathrm{Sr}$ Fallout Data, 1954-1982"

USDOE Report EML-424, January (1984a)

Larsen, R. J.

"Worldwide Deposition of ${ }^{90} \mathrm{Sr}$ through 1982"

USDOE Report EML-430, June (1984b)

Larsen, R. J.

"Worldwide Deposition of ${ }^{90} \mathrm{Sr}$ through 1983"

USDOE Report EML-444, July (1985)

Larsen, R. J. and C. G. Sanderson

"EML Surface Air Sampling Program, 1989 Data"

USDOE Report EML-541, August (1991)

Monetti, M. A. and R. J. Larsen

"Worldwide Deposition of ${ }^{90} \mathrm{Sr}$ through 1986"

USDOE Report EML-533, April (1991)

Playford, K., J. Toole and I. Adsley

"Radioactive Fallout in Air and Rain: Results to the end of 1991"

U. K. Atomic Energy Authority Report AEA-EE-0498, May (1993) 


\section{UNSCEAR}

"U.N. Scientific Committee on the Effects of Atomic Radiation - 1982 Report to the General Assembly, with Annexes. Ionizing Radiation: Sources and Biological Effects"

United Nations, New York (1982)

Volchok, H. L.

"Worldwide Deposition of ${ }^{90} \mathrm{Sr}$ through 1964"

USAEC Report HASL-245, pp. 268-284, July (1965) 
TABLE 1

SAMPLING LOCATIONS OF THE GFP FROM 1987 TO 1990

\begin{tabular}{|c|c|c|c|c|}
\hline Sampling Site & Latitude & Longitude & $\begin{array}{c}\text { Elevation } \\
\text { (m) }\end{array}$ & Sampling Unit \\
\hline Faibanks, Alaska & $64: 49^{\circ} \mathrm{N}$ & $147: 52^{\circ} \mathrm{W}$ & 143 & Ion-Column Exchange \\
\hline Nome, Alaska & $64: 30^{\circ} \mathrm{N}$ & $165: 30^{\circ} \mathrm{W}$ & 7 & ” \\
\hline Keflavik, Iceland & $63: 58^{\circ} \mathrm{N}$ & $22: 36^{\circ} \mathrm{W}$ & 56 & 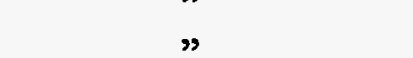 \\
\hline Anchorage, Alaska & $61: 10^{\circ} \mathrm{N}$ & $149: 59^{\circ} \mathrm{W}$ & 27 & \% \\
\hline Cold Bay, Alaska & $55: 12 \mathrm{~N}$ & $162: 43^{\circ} \mathrm{W}$ & 31 & $\eta$ \\
\hline Moosonee, Canada & $51: 16^{\circ} \mathrm{N}$ & $80: 89^{\circ} \mathrm{W}$ & 10 & ” \\
\hline Vienna, Austria & $48: 15^{\circ} \mathrm{N}$ & $16: 22^{\circ} \mathrm{E}$ & 203 & ” \\
\hline Munich, Germany & $48: 08^{\circ} \mathrm{N}$ & $11: 35^{\circ} \mathrm{E}$ & 1000 & 》 \\
\hline Klagenfurt, Austria & $46: 39^{\circ} \mathrm{N}$ & $14: 20^{\circ} \mathrm{E}$ & 448 & " \\
\hline Vermillion, South Dakota & $42: 47^{\circ} \mathrm{N}$ & $96: 56^{\circ} \mathrm{W}$ & 372 & Onen Pot \\
\hline Argonne, Illinois & $41: 42^{\circ} \mathrm{N}$ & $88: 00^{\circ} \mathrm{W}$ & 192 & Open Pot \\
\hline Chester, New Jersey & $40: 48^{\circ} \mathrm{N}$ & $74: 40^{\circ} \mathrm{W}$ & 268 & $\underset{n}{\text { Upen Bucket }}$ \\
\hline Wooster, Ohio & $40: 47^{\circ} \mathrm{N}$ & $81: 50^{\circ} \mathrm{W}$ & 367 & \\
\hline New York, New York & $40: 400 \mathrm{~N}$ & $74: 00^{\circ} \mathrm{W}$ & 56 & Open Pot \\
\hline Lajes Field, Azores & $38: 44^{\circ} \mathrm{N}$ & $27: 04^{\circ} \mathrm{W}$ & 112 & Open Bucket \\
\hline Seoul, Korea & $37: 30^{\circ} \mathrm{N}$ & $127: 00^{\circ} \mathrm{E}$ & 50 & Ion-Exchange Column \\
\hline Hiroshima, Japan & $34: 23^{\circ} \mathrm{N}$ & $132: 27^{\circ} \mathrm{E}$ & 23 & Onen Pot \\
\hline West Los Angeles, California & $34: 04^{\circ} \mathrm{N}$ & $118: 27^{\circ} \mathrm{W}$ & 125 & Upen Pot \\
\hline Birmingham, Alabama & $33: 30^{\circ} \mathrm{N}$ & $86: 55^{\circ} \mathrm{W}$ & 183 & ” \\
\hline Nagasaki, Japan & $32: 45^{\circ} \mathrm{N}$ & $129: 52^{\circ} \mathrm{E}$ & 61 & ” \\
\hline Kindley AFB, Bermuda & $32: 22^{\circ} \mathrm{N}$ & $64: 31^{\circ} \mathrm{W}$ & 8 & Ychange Column \\
\hline Houston, Texas & $29: 45^{\circ} \mathrm{N}$ & $95: 17^{\circ} \mathrm{W}$ & 22 & hange \\
\hline Miami, Florida & $25: 49^{\circ} \mathrm{N}$ & $80: 17^{\circ} \mathrm{W}$ & 4 & $\eta$ \\
\hline Taipei, Taiwan & $25: 05^{\circ} \mathrm{N}$ & $121: 31^{\circ} \mathrm{E}$ & 50 & \\
\hline Lihue, Hawaii & $21: 59 \mathrm{~N}$ & $159: 21^{\circ} \mathrm{W}$ & 35 & Open Pot \\
\hline Mauna Loa, Hawaii & $19: 32^{\circ} \mathrm{N}$ & $155: 31^{\circ} \mathrm{W}$ & 3401 & Ion-Exchange Column \\
\hline Wake Island & $19: 17^{\circ} \mathrm{N}$ & $166: 39^{\circ} \mathrm{E}$ & 3 & Open Pot \\
\hline San Juan, Puerto Rico & $18: 26 \mathrm{~N}$ & $66: 00^{\circ} \mathrm{W}$ & 10 & Ion-Exchange Column \\
\hline Johnston Island & $16: 45^{\circ} \mathrm{N}$ & $169: 32^{\circ} \mathrm{W}$ & 0 & $"$ \\
\hline Clark AFB, Philippines & $15: 11^{\circ} \mathrm{N}$ & $120: 33^{\circ} \mathrm{E}$ & 10 & 》 \\
\hline Bangkok, Thailand & $13: 44^{\circ} \mathrm{N}$ & $100: 30^{\circ} \mathrm{E}$ & 23 & \\
\hline Anderson AFB, Guam & $13: 35 \mathrm{~N}$ & $144: 55^{\circ} \mathrm{E}$ & 185 & Open Pot \\
\hline Yap Island & $9: 31 \% \mathrm{~N}$ & $138: 08^{\circ} \mathrm{E}$ & 18 & Ion-Exchange Column \\
\hline Panama Canal Zone & $8: 55^{\circ} \mathrm{N}$ & $79: 36^{\circ} \mathrm{W}$ & 10 & 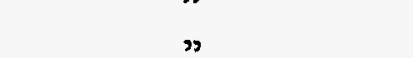 \\
\hline Truk Island & $7: 28^{\circ} \mathrm{N}$ & $151: 51^{\circ} \mathrm{E}$ & 2 & $"$ \\
\hline Koror Island & $7: 21^{\circ} \mathrm{N}$ & $134: 31^{\circ} \mathrm{E}$ & 31 & " \\
\hline
\end{tabular}


TABLE 1 (Cont'd)

SAMPLING LOCATIONS OF THE GFP FROM 1987 TO 1990

\begin{tabular}{|c|c|c|c|c|}
\hline Sampling Site & Latitude & Longitude & $\begin{array}{l}\text { Elevation } \\
\text { (m) }\end{array}$ & Sampling Unit \\
\hline Majoro Island & $07: 05^{\circ} \mathrm{N}$ & $171: 23^{\circ} \mathrm{E}$ & 3 & Ion-Exchange Column \\
\hline Ponape Island & $06: 58^{\circ} \mathrm{N}$ & $158: 13^{\circ} \mathrm{E}$ & 38 & $"$ \\
\hline Karawa, Zaire & $03: 14 \mathrm{~N}$ & $020: 17^{\circ} \mathrm{E}$ & 750 & $"$ \\
\hline Mbandaka, Zaire & $00: 03^{\circ} \mathrm{N}$ & $018: 28^{\circ} \mathrm{E}$ & 350 & $"$ \\
\hline Kikuyu, Kenya & $01: 13^{\circ} \mathrm{S}$ & $036: 38^{\circ} \mathrm{E}$ & 2074 & Open Pot \\
\hline Belem, Brazil & $01: 27^{\circ} \mathrm{S}$ & $048: 29^{\circ} \mathrm{E}$ & 8 & Ion-Exchange Column \\
\hline Guayaquil, Ecuador & $02: 10^{\circ} \mathrm{S}$ & $079: 52^{\circ} \mathrm{E}$ & 7 & $"$ \\
\hline Lima, Peru & $12: 01^{\circ} \mathrm{S}$ & $077: 07^{\circ} \mathrm{E}$ & 30 & $"$ \\
\hline Darwin, Australia & $12: 28^{\circ} \mathrm{S}$ & $130: 51^{\circ} \mathrm{E}$ & 30 & $"$ \\
\hline Tutuila, American Samoa & $14: 16^{\circ} \mathrm{S}$ & $170: 43^{\circ} \mathrm{W}$ & 77 & Open Bucket \\
\hline Chacaltaya, Bolivia & $16: 21^{\circ} \mathrm{S}$ & $068: 08^{\circ} \mathrm{W}$ & 5222 & Ion-Exchange Column \\
\hline Harare, Zimbabwe & $17: 48^{\circ} \mathrm{S}$ & $031: 03^{\circ} \mathrm{E}$ & 1495 & Open Pot \\
\hline Suva, Fiji & $18: 09^{\circ} \mathrm{S}$ & $178: 25^{\circ} \mathrm{W}$ & 11 & Ion-Exchange Column \\
\hline Townsville, Australia & $19: 18^{\circ} \mathrm{S}$ & $146: 48^{\circ} \mathrm{E}$ & 4 & $"$ \\
\hline Rio de Janeiro, Brazil & $22: 54^{\circ} \mathrm{S}$ & $043: 13^{\circ} \mathrm{W}$ & 9 & Open Pot \\
\hline Antofagasta, Chile & $23: 37^{\circ} \mathrm{S}$ & $070: 25^{\circ} \mathrm{W}$ & 30 & Ion-Exchange Column \\
\hline Pretoria, South Africa & $25: 45^{\circ} \mathrm{S}$ & $028: 14^{\circ} \mathrm{E}$ & 1369 & Open Pot \\
\hline Easter Island, Chile & $27: 10^{\circ} \mathrm{S}$ & $109: 26^{\circ} \mathrm{W}$ & 41 & Ion-Exchange Column \\
\hline Brisbane, Australia & $27: 28^{\circ} \mathrm{S}$ & $153: 02^{\circ} \mathrm{W}$ & 42 & $"$ \\
\hline Durban, South Africa & $29: 52^{\circ} \mathrm{S}$ & $030: 59^{\circ} \mathrm{E}$ & 156 & Open Pot \\
\hline Perth, Australia & $31: 57^{\circ} \mathrm{S}$ & $115: 51^{\circ} \mathrm{E}$ & 64 & Ion-Exchange Column \\
\hline Santiago, Chile & $33: 27^{\circ} \mathrm{S}$ & $070: 42^{\circ} \mathrm{W}$ & 520 & ” \\
\hline Sydney, Australia & $33: 52^{\circ} \mathrm{S}$ & $151: 12^{\circ} \mathrm{E}$ & 42 & " \\
\hline Buenos Aires, Argentina & $34: 37^{\circ} \mathrm{S}$ & $058: 26^{\circ} \mathrm{W}$ & 20 & $"$ \\
\hline Adelaide, Australia & $34: 56^{\circ} \mathrm{S}$ & $138: 35^{\circ} \mathrm{E}$ & 43 & $"$ \\
\hline Melbourne, Australia & $37: 49^{\circ} \mathrm{S}$ & $144: 58^{\circ} \mathrm{E}$ & 47 & $"$ \\
\hline Wellington, New Zealand & $41: 17^{\circ} \mathrm{S}$ & $174: 46^{\circ} \mathrm{E}$ & 34 & $"$ \\
\hline Puerto Montt, Chile & $41: 26^{\circ} \mathrm{S}$ & $073: 07^{\circ} \mathrm{W}$ & 110 & $"$ \\
\hline Hobart, Australia & $42: 53^{\circ} \mathrm{S}$ & $147: 20^{\circ} \mathrm{E}$ & 54 & $"$ \\
\hline Punta Arenas, Chile & $53: 00^{\circ} \mathrm{S}$ & $070: 50^{\circ} \mathrm{W}$ & 74 & $"$ \\
\hline Antarticia, Chile & $62: 56^{\circ} \mathrm{S}$ & $060: 36^{\circ} \mathrm{W}$ & 16 & $"$ \\
\hline
\end{tabular}


TABLE 2

RESULTS OF QUALITY CONTROL BLANK SAMPLES SUBMITTED WITH SAMPLES COLLECTED FROM 1987 TO 1990 ( $\mathrm{mBq}{ }^{90} \mathrm{Sr}$ per Sample \pm Standard Deviation)

\begin{tabular}{|c|c|c|c|}
\hline Laboratory $\mathrm{A}^{\mathrm{a}}$ & Laboratory $\mathrm{B}^{\mathrm{b}}$ & Laboratory $\mathrm{C}^{\mathrm{C}}$ & Laboratory $\mathrm{D}^{\mathrm{d}}$ \\
\hline $0.0 \pm 1.7$ & $2.2 \pm 6.0$ & $0.0 \pm 6.7$ & $0.0 \pm 1.7$ \\
\hline $0.0 \pm 1.7$ & $8.7 \pm 2.8$ & $16.7 \pm 3.3$ & $3.3 \pm 3.3$ \\
\hline $0.0 \pm 1.7$ & $3.7 \pm 3.0$ & $1.7 \pm 8.3$ & $0.0 \pm 1.7$ \\
\hline $0.0 \pm 3.3$ & $7.8 \pm 2.9$ & $1.7 \pm 16.7$ & $0.0 \pm 1.7$ \\
\hline $3.3 \pm 1.7$ & & $5.0 \pm 4.2$ & $1.7 \pm 1.7$ \\
\hline $143.3 \pm 1.7$ & & $0.0 \pm 5.8$ & $0.0 \pm 1.7$ \\
\hline $3.3 \pm 1.7$ & & $0.0 \pm 5.0$ & $1.7 \pm 1.7$ \\
\hline $6.7 \pm 1.7$ & & $0.3 \pm 4.2$ & $0.0 \pm 1.7$ \\
\hline $11.7 \pm 1.7$ & & $0.0 \pm 3.3$ & $0.0 \pm 1.7$ \\
\hline $0.0 \pm 1.7$ & & $3.3 \pm 2.5$ & $1.7 \pm 3.3$ \\
\hline $0.0 \pm 1.7$ & & $6.7 \pm 3.3$ & $6.7 \pm 3.3$ \\
\hline $0.0 \pm 1.7$ & & $0.0 \pm 9.2$ & \\
\hline & & $10.0 \pm 3.3$ & \\
\hline & & $8.3 \pm 3.3$ & \\
\hline & & $16.7 \pm 2.5$ & \\
\hline & & $0.0 \pm 5.8$ & \\
\hline & & $1.7 \pm 1.7$ & \\
\hline & & $0.0 \pm 4.2$ & \\
\hline & & $0.0 \pm 7.5$ & \\
\hline & & $0.0 \pm 10.8$ & \\
\hline & & $0.0 \pm 2.5$ & \\
\hline & & $0.0 \pm 1.7$ & \\
\hline & & $5.0 \pm 1.7$ & \\
\hline & & $1.7 \pm 5.8$ & \\
\hline & & $0.0 \pm 6.7$ & \\
\hline & & $48.3 \pm 10.8$ & \\
\hline & & $3.3 \pm 1.7$ & \\
\hline & & $3.3 \pm 8.3$ & \\
\hline & & $1.7 \pm 3.3$ & \\
\hline & & $1.7 \pm 5.0$ & \\
\hline & & $5.0 \pm 1.7$ & \\
\hline & & $1.7 \pm 1.7$ & \\
\hline & & $0.0 \pm 5.8$ & \\
\hline & & $25.0 \pm 2.5$ & \\
\hline & & $0.0 \pm 0.8$ & \\
\hline
\end{tabular}

a Mean Blank Value $=12.5 \pm 40.7$

${ }^{b}$ Mean Blank Value $=5.6 \pm 3.1$

${ }^{\circ}$ Mean Blank Value $=4.9 \pm 9.4$

${ }^{\mathrm{d}}$ Mean Blank Value $=1.3 \pm 2.0$ 


\section{TABLE 3}

RESULTS OF QUALITY CONTROL REFERENCE SAMPLES SUBMITED WITH SAMPLES COLLECTED FROM 1987 TO 1990 ( $\mathrm{mBq}{ }^{90} \mathrm{Sr}$ per Sample \pm Standard Deviation)

\begin{tabular}{cccrrr}
\hline Added & Reported & \% Recovered & Added & Reported & \% Recover \\
\hline Laboratory - A & & & & & \\
& & & & & \\
55.0 & $53.3 \pm 1.7$ & 95 & 106.7 & $88.3 \pm 1.7$ & 84 \\
60.0 & $56.7 \pm 5.0$ & 95 & 108.3 & $161.7 \pm 1.7$ & 149 \\
53.3 & $43.3 \pm 5.0$ & 81 & 80.0 & $193.3 \pm 1.7$ & 242 \\
98.3 & $75.0 \pm 1.7$ & 76 & & &
\end{tabular}

Mean $\%$ Recovery $=117 \pm 60$

Laboratory - B

$\begin{array}{llllll}60.5 & 55.0 \pm 5.0 & 91 & 85.7 & 76.5 \pm 3.9 & 89 \\ 82.7 & 78.3 \pm 5.4 & 95 & 58.5 & 54.2 \pm 3.7 & 93\end{array}$

Mean $\%$ Recovery $=92 \pm 3$

Laboratory - C

$\begin{array}{rrrrrr}41.7 & 45.0 \pm 12.5 & 108 & 25.0 & 23.3 \pm 5.0 & 93 \\ 75.0 & 800 \pm 5.0 & 107 & 46.7 & 45.0 \pm 5.0 & 96 \\ 46.7 & 45.0 \pm 5.0 & 90 & 60.0 & 51.7 \pm 2.5 & 86 \\ 68.3 & 65.0 \pm 6.7 & 91 & 78.3 & 78.3 \pm 4.2 & 100 \\ 51.7 & 61.7 \pm 5.0 & 116 & 35.0 & 45.0 \pm 5.0 & 129 \\ 20.0 & 23.3 \pm 5.0 & 116 & 53.3 & 63.3 \pm 5.8 & 119 \\ 83.3 & 88.3 \pm 8.3 & 106 & 75.0 & 73.3 \pm 10.0 & 98 \\ 33.3 & 36.7 \pm 5.0 & 110 & 23.3 & 45.0 \pm 12.5 & 197 \\ 70.0 & 61.7 \pm 4.2 & 88 & 70.0 & 76.7 \pm 5.0 & 110 \\ 60.0 & 63.3 \pm 8.3 & 106 & 43.3 & 50.0 \pm 3.3 & 115 \\ 61.7 & 76.7 \pm 5.8 & 124 & 21.7 & 30.0 \pm 3.3 & 138 \\ 23.3 & 30.0 \pm 4.2 & 129 & 66.7 & 56.7 \pm 3.3 & 85 \\ 120.0 & 131.7 \pm 12.5 & 110 & 25.0 & 20.0 \pm 6.7 & 80 \\ 61.7 & 60.0 \pm 4.2 & 97 & 28.3 & 11.7 \pm 1.7 & 41 \\ 51.7 & 58.3 \pm 5.8 & 113 & 41.7 & 13.3 \pm 3.3 & 32 \\ 90.0 & 81.7 \pm 3.3 & 91 & 51.7 & 21.7 \pm 1.7 & 42 \\ 25.0 & 20.0 \pm 4.2 & 80 & 55.0 & 23.3 \pm 1.7 & 42\end{array}$

Mean \% Recovery $=100 \pm 31$ 
TABLE 3 (Cont'd.)

\begin{tabular}{crrrrr}
\hline Added & Reported & \% Recovered & Added & Reported & \% Recovered \\
\hline Laboratory - D & & & & & \\
70.0 & $60.0 \pm 3.3$ & 86 & 30.0 & $31.7 \pm 1.7$ & 113 \\
40.0 & $36.7 \pm 3.3$ & 92 & 43.3 & $40.0 \pm 3.3$ & 93 \\
40.0 & $28.3 \pm 3.3$ & 73 & 58.3 & $60.0 \pm 3.3$ & 101 \\
41.7 & $26.7 \pm 3.3$ & 63 & 76.7 & $71.7 \pm 3.3$ & 94 \\
51.7 & $51.7 \pm 6.7$ & 100 & 120.0 & $126.7 \pm 5.0$ & 107 \\
103.3 & $95.0 \pm 10.0$ & 91 & 45.0 & $35.0 \pm 3.3$ & 75 \\
75.0 & $65.0 \pm 6.7$ & 87 & & & \\
Mean \% Recovery $=90 \pm 14$ & & & & \\
\hline
\end{tabular}


TABLE 4

QUARTERLY ${ }^{90} \mathrm{Sr}$ DEPOSITION $\left(\mathrm{Bq} \mathrm{m}^{-2}\right)$ AND PRECIPITATION $(\mathrm{cm})$ DATA FOR INDIVIDUAL SAMPLING LOCATIONS FROM 1987 TO 1990

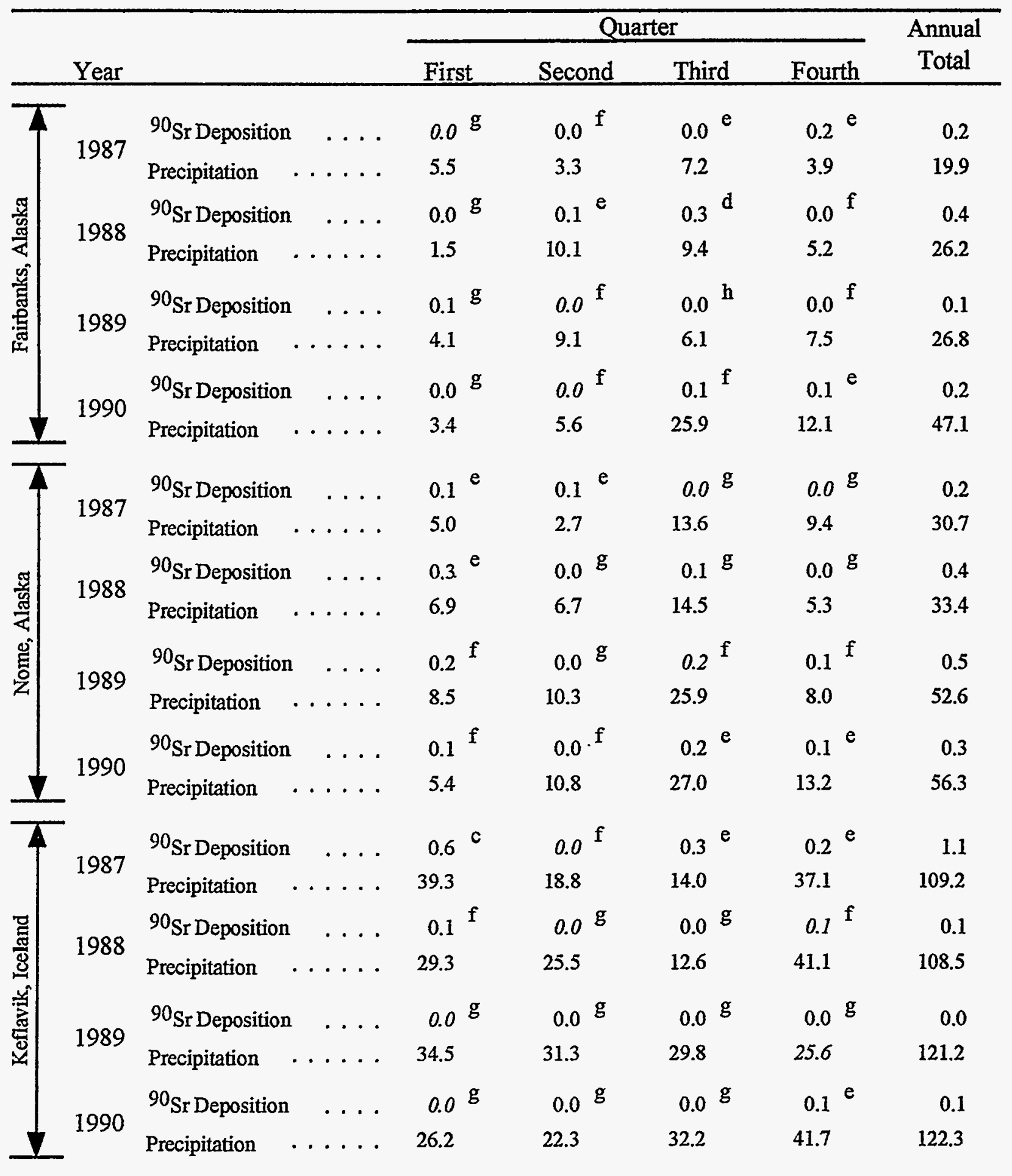

Notes: - indicates that no data is available

Italized numbers indicate the data is estimated through extrapolation or approximation

Relative errors of $90 \mathrm{Sr}$ analyses are given as: $a=0$ to $1 \%, b=>1$ to $5 \%, c=>5$ to $10 \%, d=>10$ to $20 \%$, $\mathrm{e}=>20$ to $50 \%, \mathrm{f}=>50$ to $100 \%, \mathrm{~g}=>100 \%, \mathrm{~h}=$ can not be determined since reported value is zero. 
TABBLE 4 (Cont'd)

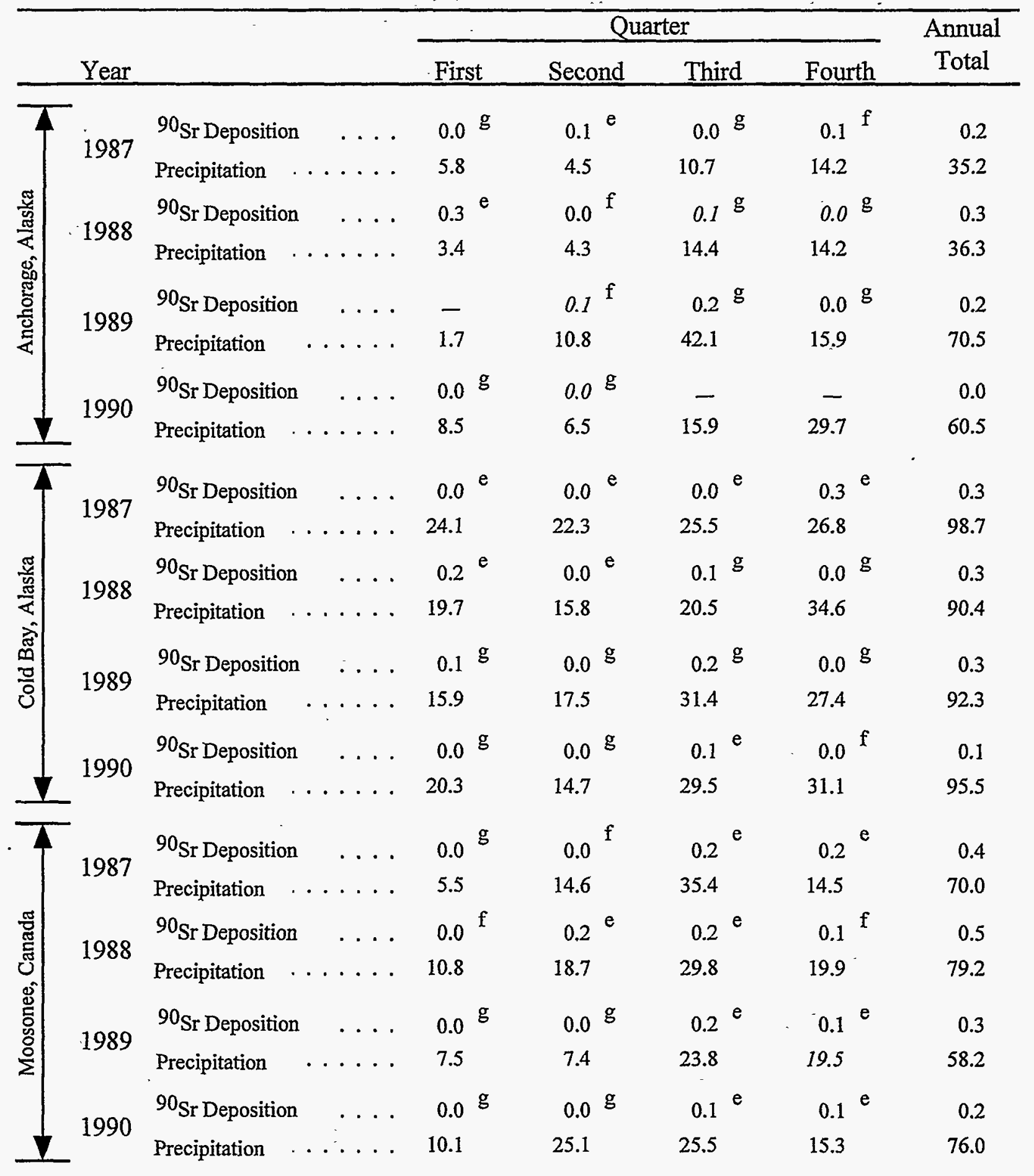


TABLE 4 (Cont'd)

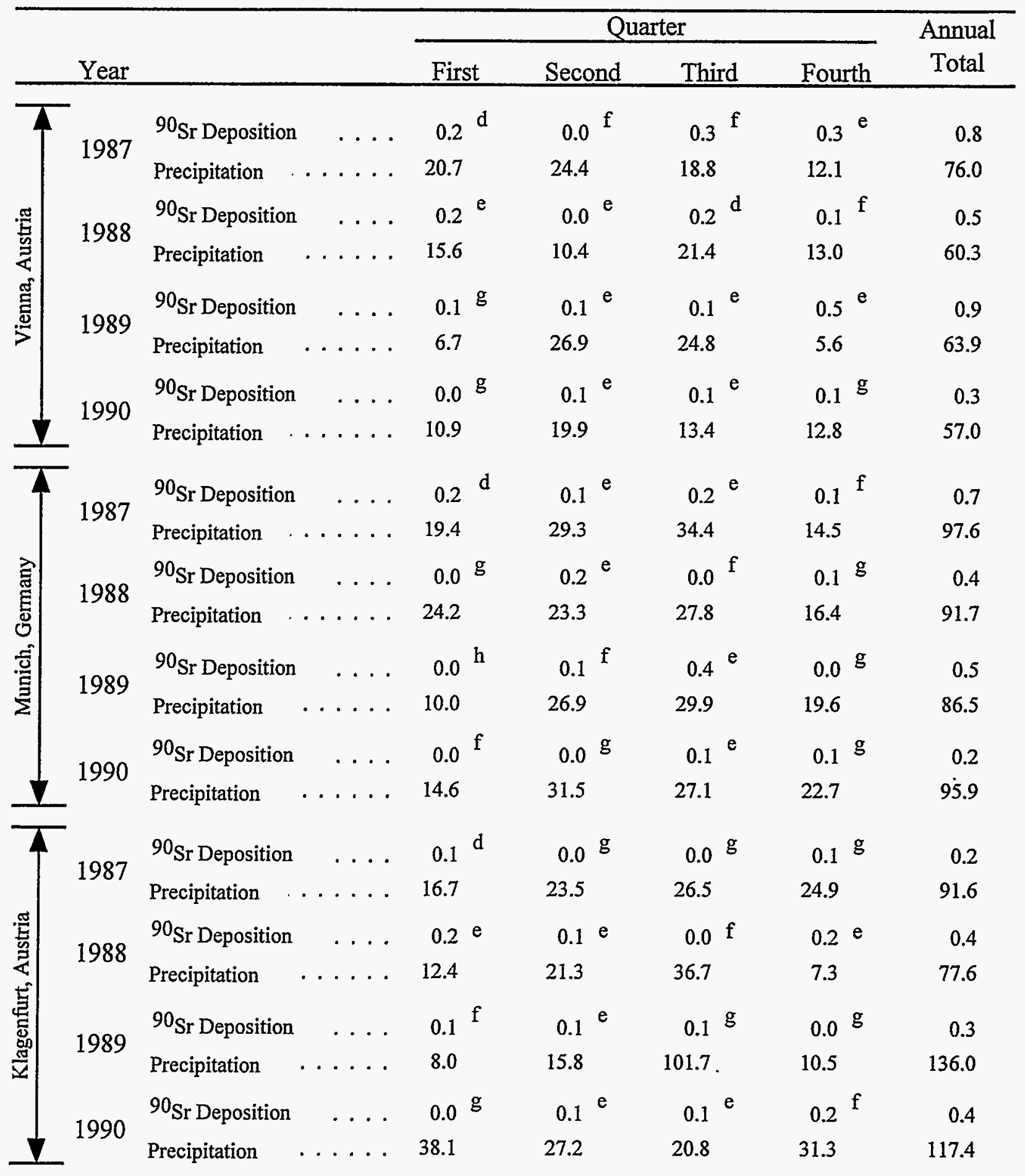


TABLE 4 (Cont'd)

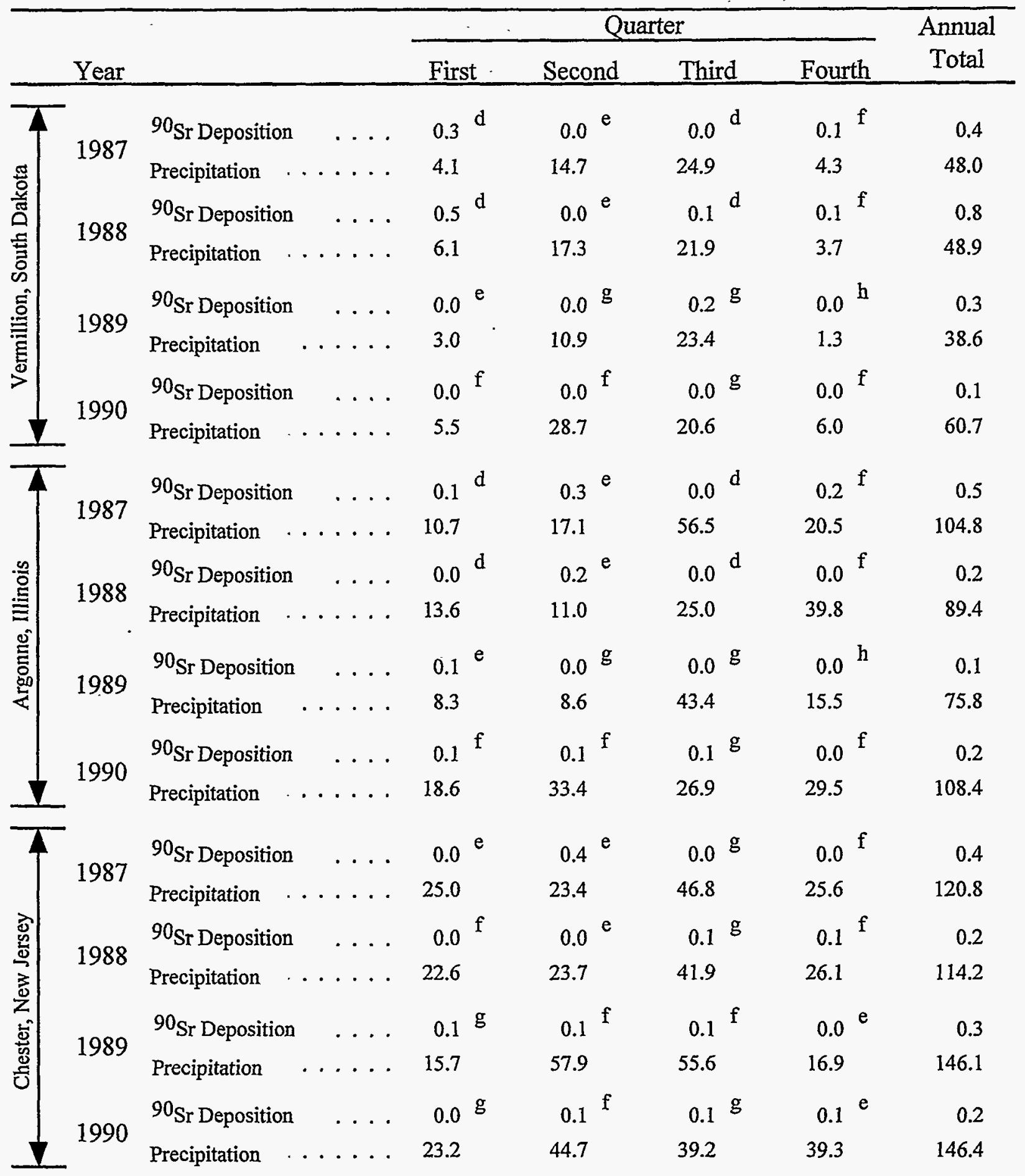


TABLE 4 (Cont'd)

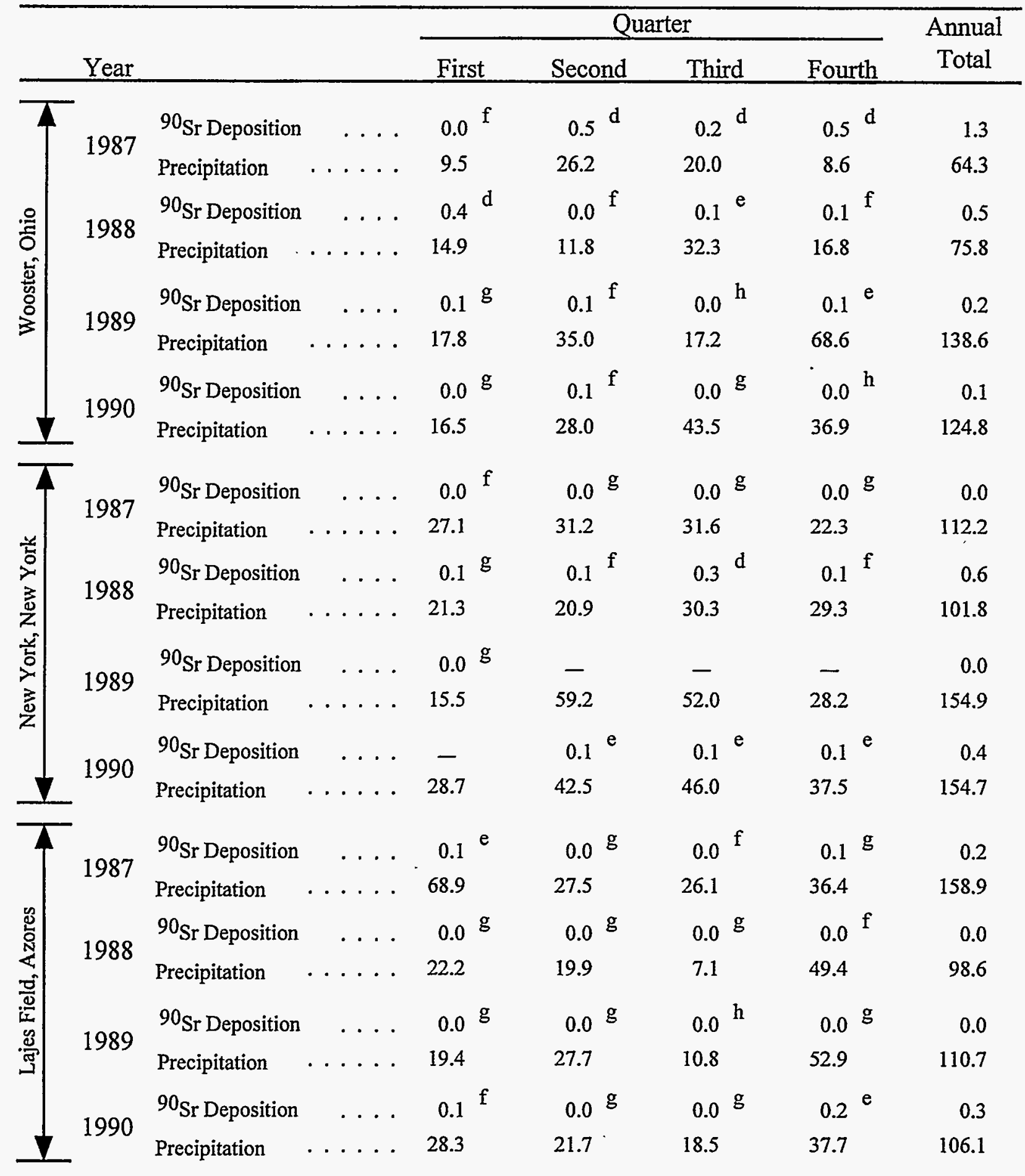


TABLE 4 (Cont'd)




TABLE 4 (Cont'd)

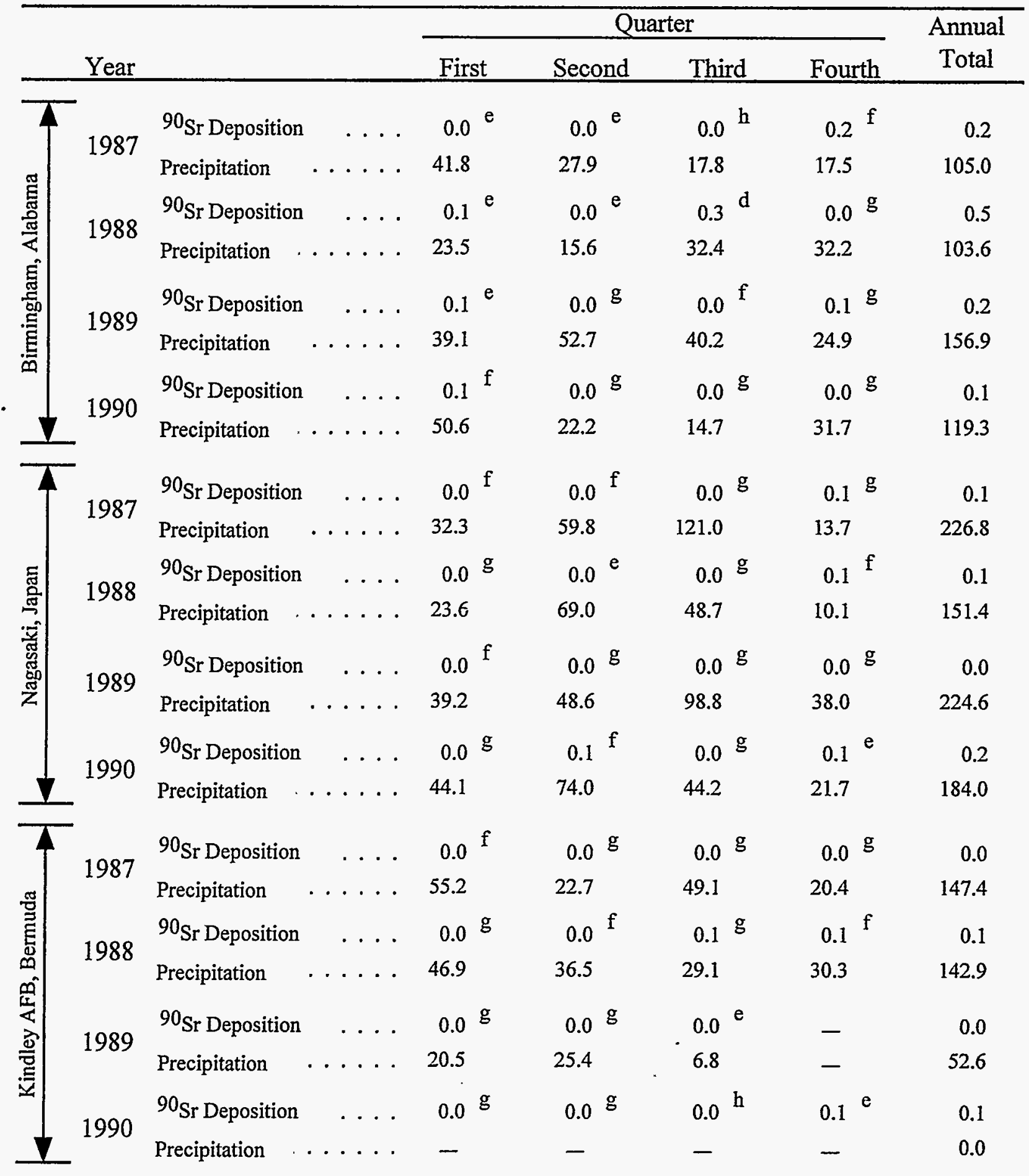


TABLE 4 (Cont'd)

\begin{tabular}{|c|c|c|c|c|c|c|c|c|}
\hline & & & & & & & & Annual \\
\hline & Year & & & First & Second & Third & Fourth & Total \\
\hline 4 & 1007 & ${ }^{90} \mathrm{Sr}$ Deposition & $\ldots$ & $0.0^{\mathrm{f}}$ & $0.1^{d}$ & $0.0^{\mathrm{d}}$ & $0.2^{\mathrm{d}}$ & 0.3 \\
\hline & 1981 & Precipitation & $\ldots \ldots$ & 20.7 & 38.6 & 24.8 & 17.9 & 102.0 \\
\hline $\mathscr{z}$ & & ${ }^{90} \mathrm{Sr}$ Deposition & $\ldots$ & $0.2^{\mathrm{d}}$ & $0.1^{f}$ & $0.1^{\mathrm{e}}$ & $0.1^{\mathrm{f}}$ & 0.4 \\
\hline$\stackrel{x}{6}$ & 1988 & Precipitation & $\ldots$ & 18.9 & 11.6 & 20.2 & 7.5 & 58.3 \\
\hline 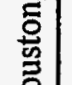 & & ${ }^{90} \mathrm{Sr}$ Deposition & $\ldots$ & $0.1^{\mathrm{g}}$ & $0.0^{\mathrm{f}}$ & $0.0^{h}$ & $0.0^{\mathrm{e}}$ & 0.1 \\
\hline & 1989 & Precipitation & $\ldots \ldots$ & 25.6 & 80.4 & 32.5 & 16.5 & 155.0 \\
\hline & & ${ }^{90}$ Sr Deposition & $\ldots$ & $0.0^{\mathrm{g}}$ & $0.0^{\mathrm{f}}$ & $0.0^{\mathrm{g}}$ & $0.0^{\mathrm{h}}$ & 0.0 \\
\hline & 1990 & Precipitation & $\ldots$ & 31.4 & 26.0 & 22.0 & 21.8 & 101.2 \\
\hline & 1087 & ${ }^{90} \mathrm{Sr}$ Deposition & . & $0.1^{\mathrm{d}}$ & $0.0^{\mathrm{e}}$ & $0.0^{\mathrm{g}}$ & $0.0^{\mathrm{g}}$ & 0.1 \\
\hline & 1981 & Precipitation & $\ldots \ldots$ & 18.6 & 27.6 & 22.2 & 34.4 & 102.8 \\
\hline 꽁 & & ${ }^{90}$ Sr Deposition & . & $0.2^{\mathrm{f}}$ & $0.0^{\mathrm{g}}$ & $0.1^{\mathrm{g}}$ & $0.1^{\mathrm{g}}$ & 0.3 \\
\hline$\frac{\circ}{\square}$ & 1988 & Precipitation & $\ldots \ldots$ & 7.3 & 42.1 & 55.6 & 6.0 & 111.0 \\
\hline 馬 & 1080 & ${ }^{90} \mathrm{Sr}$ Deposition & 1 & $0.2^{\mathrm{e}}$ & $0.1^{\mathrm{f}}$ & $0.0^{g}$ & $0.2^{\mathrm{e}}$ & 0.4 \\
\hline & 1989 & Precipitation & $\ldots \ldots$ & 5.8 & 35.5 & 58.2 & 13.7 & 113.1 \\
\hline & 1000 & ${ }^{90} \mathrm{Sr}$ Deposition & $\cdots$ & $0.0^{f}$ & $0.0^{\mathrm{g}}$ & $0.0^{\mathrm{g}}$ & $0.1^{\mathrm{e}}$ & 0.2 \\
\hline & 1990 & Precipitation . & $\ldots \ldots$ & 9.4 & 54.8 & 48.0 & 19.1 & 131.3 \\
\hline & 1007 & ${ }^{90} \mathrm{Sr}$ Deposition & & $0.1^{\mathrm{d}}$ & - & $0.1^{\mathrm{f}}$ & $0.2^{\mathrm{f}}$ & 0.0 \\
\hline & 1987 & Precipitation & $\cdots$ & 17.4 & - & - & 48.7 & 66.1 \\
\hline F & 1000 & ${ }^{90}$ Sr Deposition & & $0.0^{\mathrm{g}}$ & $0.2^{\mathrm{e}}$ & $0.1^{f}$ & $0.2^{\mathrm{f}}$ & 0.4 \\
\hline : & 1988 & Precipitation & $\cdots$ & 45.2 & 87.4 & 117.6 & 28.2 & 278.3 \\
\hline 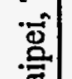 & 1080 & ${ }^{90} \mathrm{Sr}$ Deposition & & $0.2^{\mathrm{e}}$ & $0.0^{\mathrm{g}}$ & $0.0^{\mathrm{g}}$ & $0.0^{\mathrm{f}}$ & 0.2 \\
\hline & 1989 & Precipitation & $\cdots$ & 20.0 & 54.6 & 125.7 & 27.0 & 227.2 \\
\hline & 1000 & ${ }^{90} \mathrm{Sr}$ Deposition & & $0.3^{d}$ & $0.0^{\mathrm{g}}$ & - & $0.1^{\mathrm{e}}$ & 0.4 \\
\hline & 1990 & Precipitation & & 47.5 & 64.4 & 90.0 & 11.6 & 213.4 \\
\hline
\end{tabular}


TABLE 4 (Cont'd)

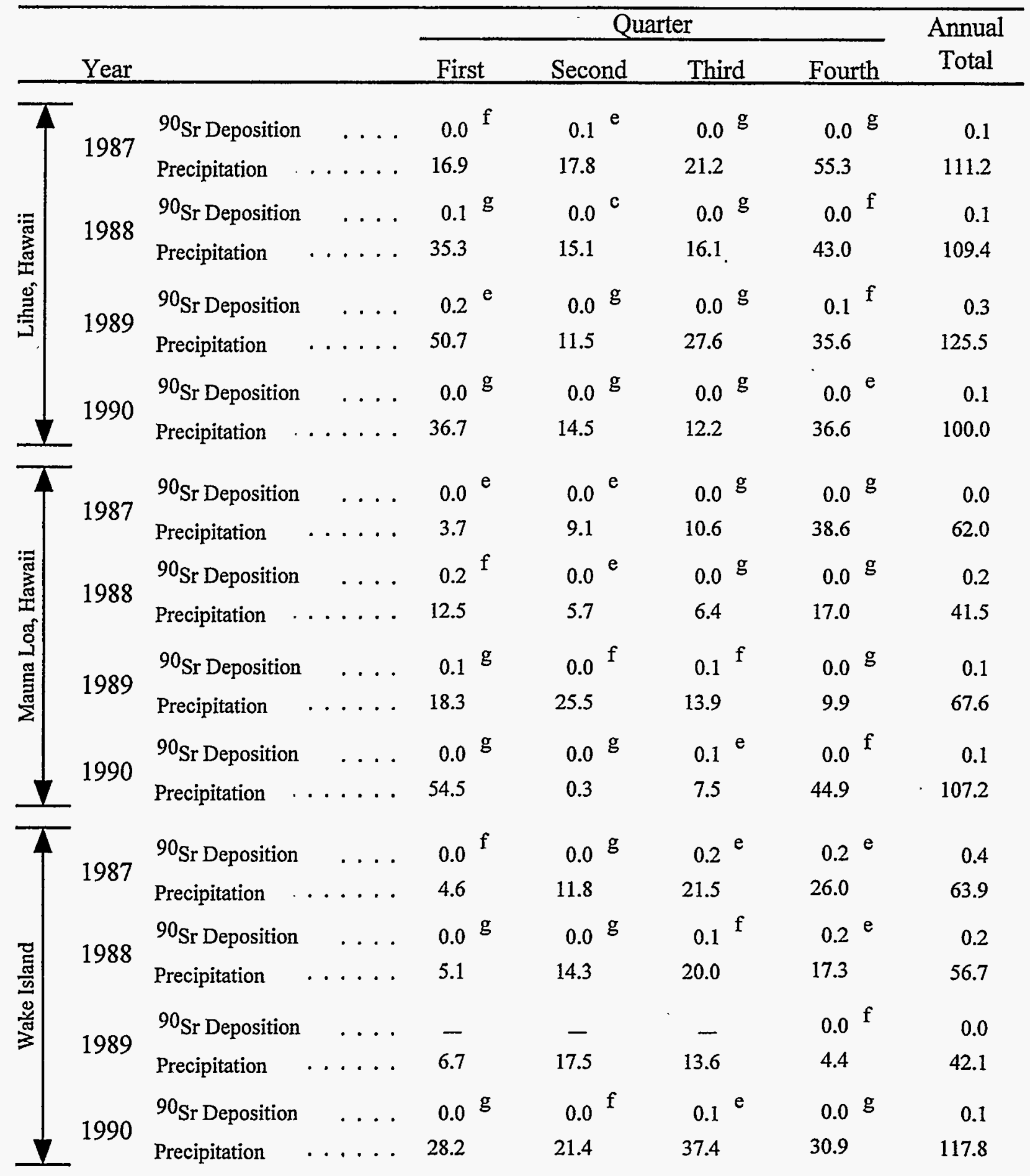




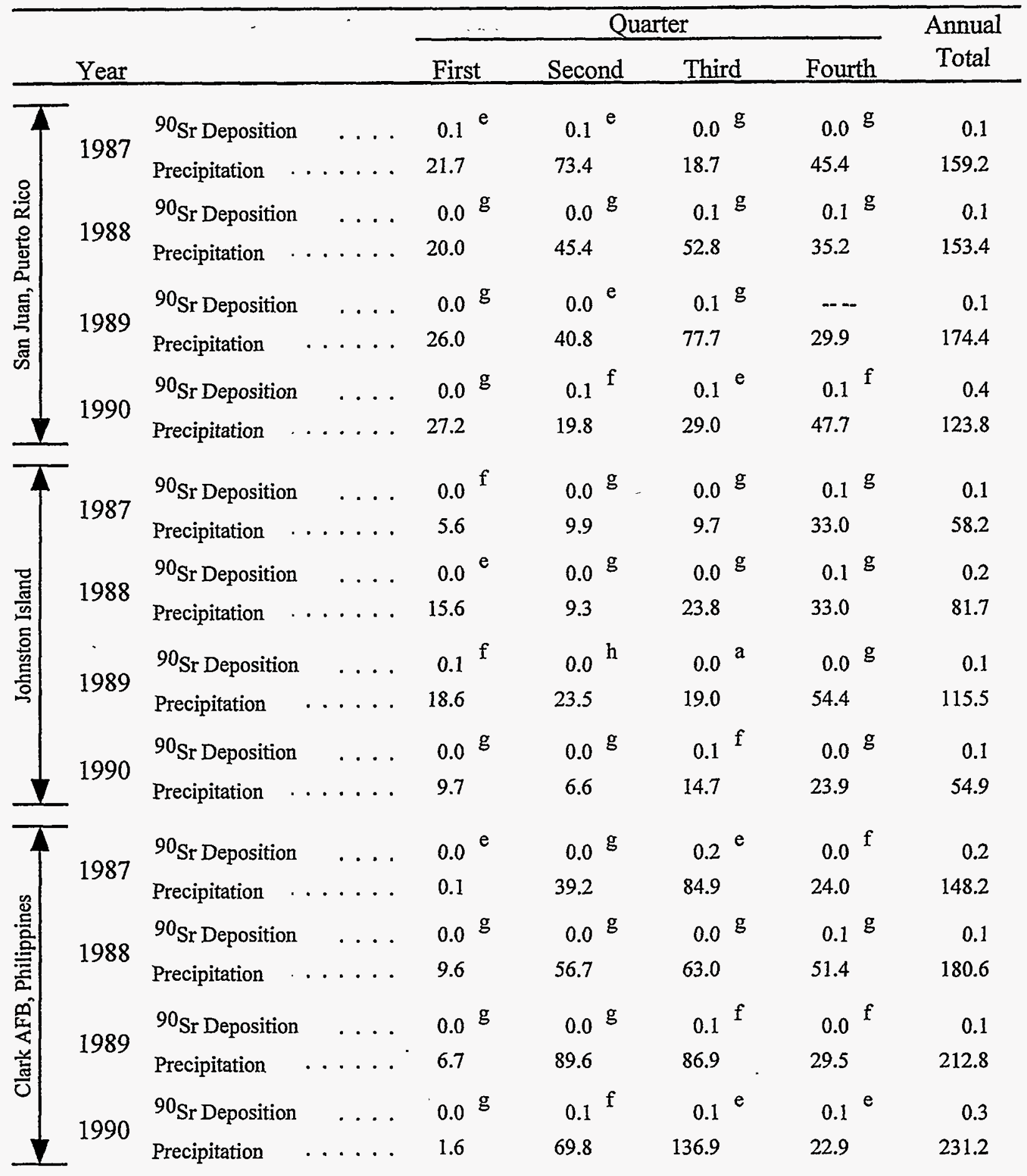


TABLE 4 (Cont'd)

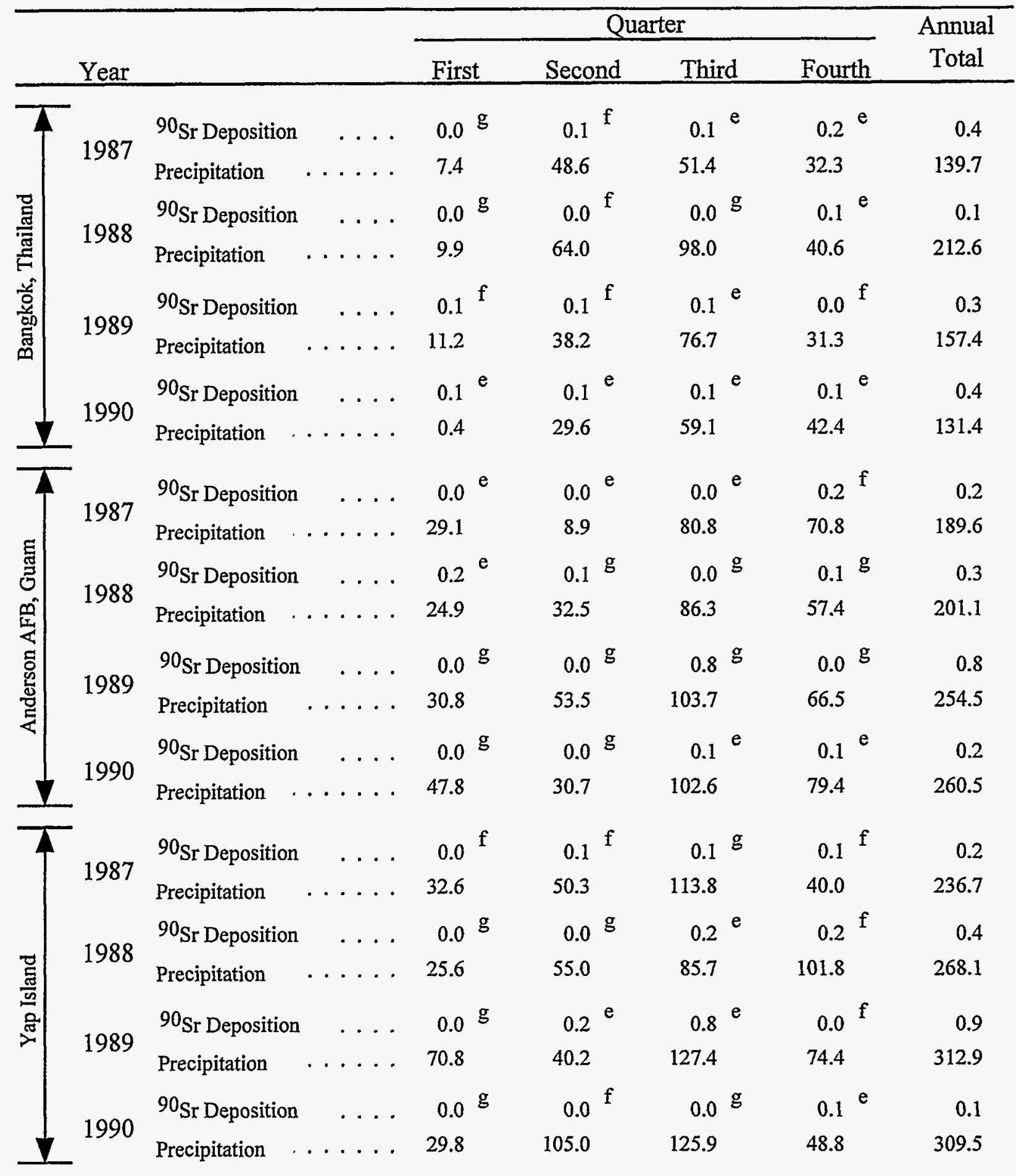


TABLE 4 (Cont'd)

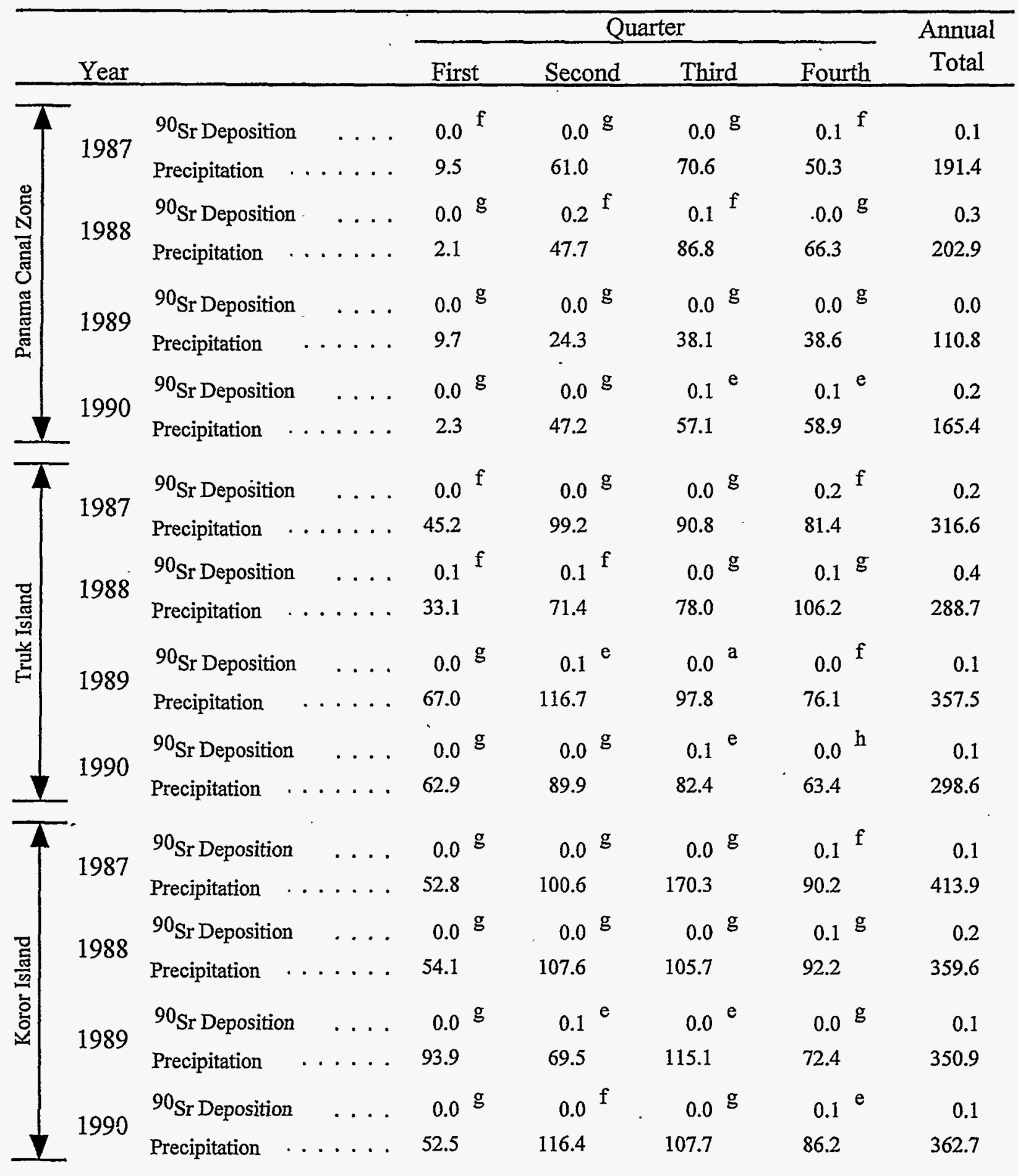


TABLE 4 (Cont'd)

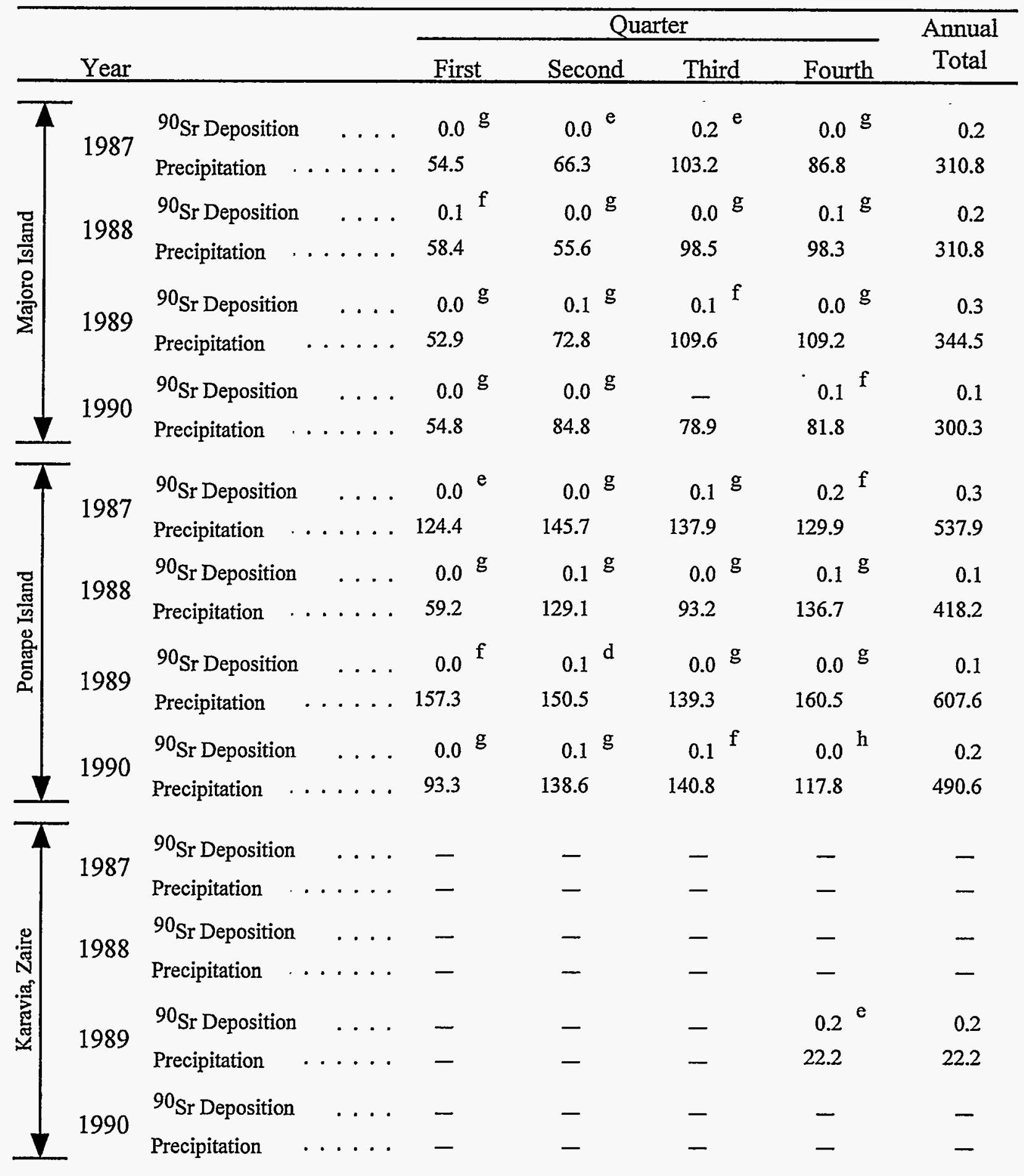


TABLE 4 (Cont'd)

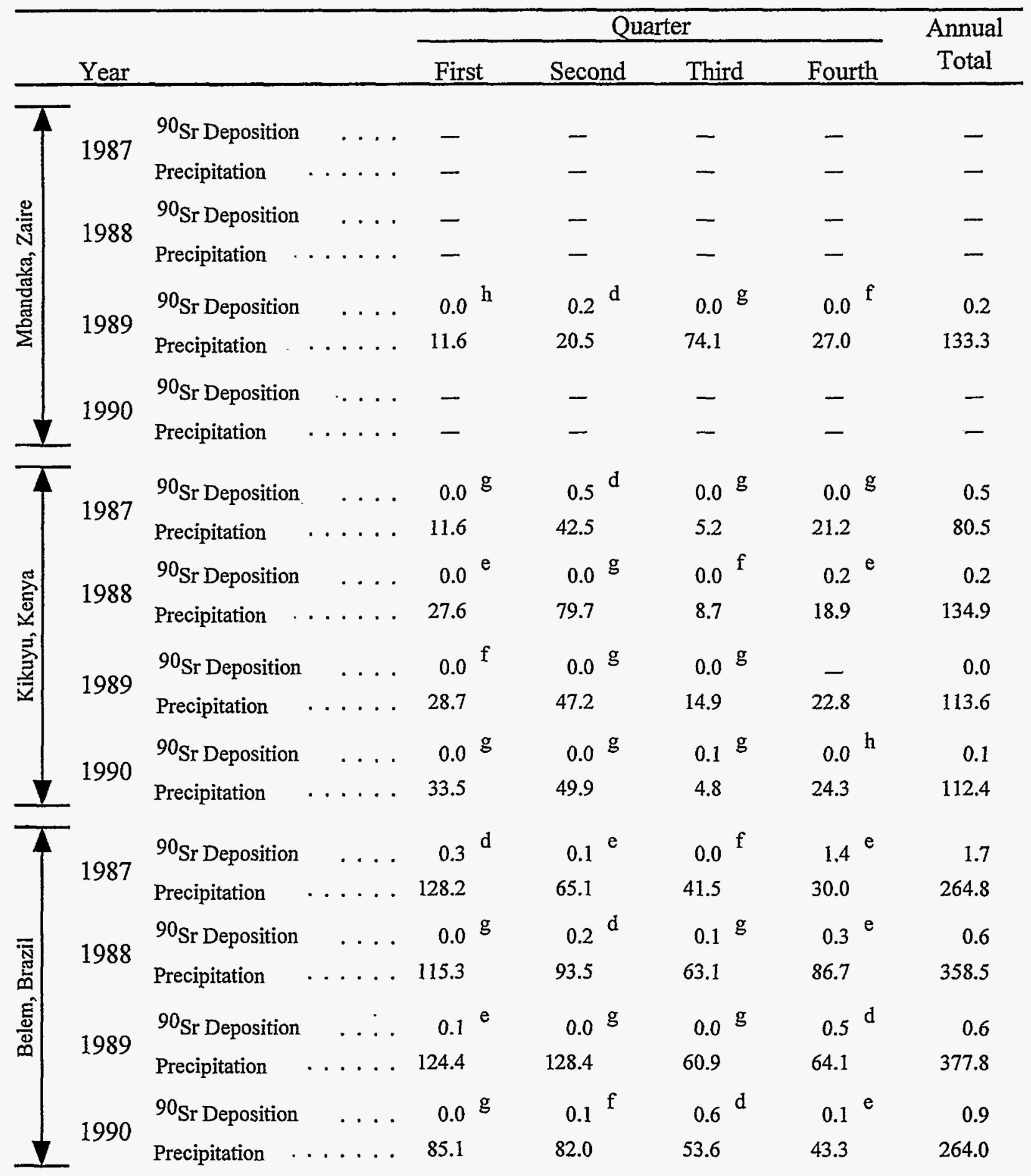


TABLE 4 (Cont'd)

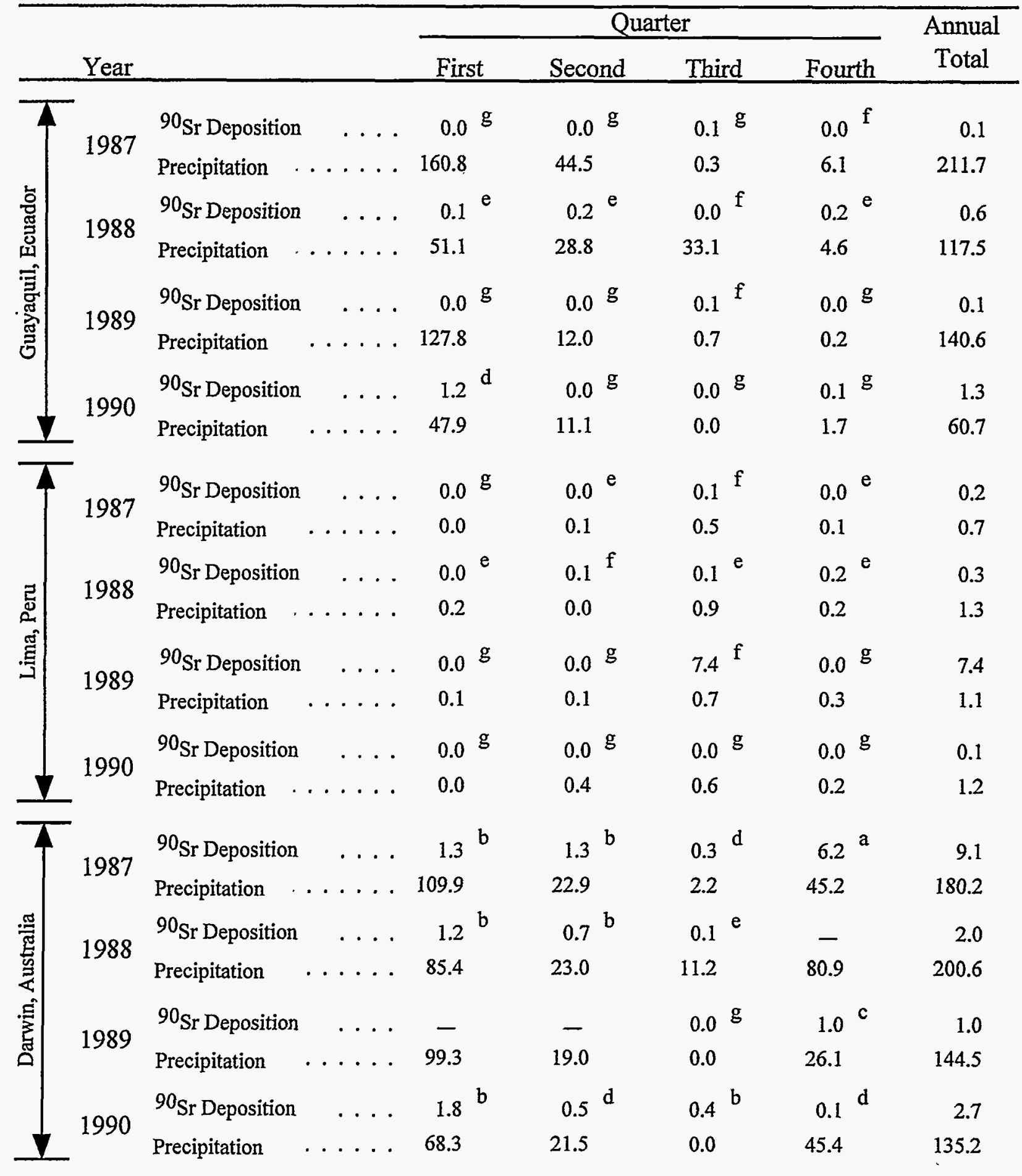


TABLE 4 (Cont'd)

\begin{tabular}{|c|c|c|c|c|c|c|c|c|}
\hline \multirow{2}{*}{\multicolumn{2}{|c|}{ Year }} & & & \multicolumn{4}{|c|}{ Quarter } & \multirow{2}{*}{$\begin{array}{c}\text { Annual } \\
\text { Total }\end{array}$} \\
\hline & & & . & First & Second & Third & Fourth & \\
\hline \multirow{8}{*}{ 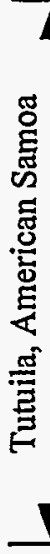 } & \multirow{2}{*}{1987} & ${ }^{90} \mathrm{Sr}$ Deposition & 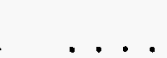 & $0.0^{\mathrm{e}}$ & $0.0^{\mathrm{g}}$ & $0.0^{\mathrm{e}}$ & $0.0^{e}$ & 0.0 \\
\hline & & Precipitation & $\ldots$ & 84.9 & 48.4 & 12.5 & 40.9 & 186.7 \\
\hline & \multirow{2}{*}{1988} & ${ }^{90} \mathrm{Sr}$ Deposition & & $0.4^{\mathrm{d}}$ & $0.0^{f}$ & $0.1^{\mathrm{e}}$ & $0.1^{f}$ & 0.6 \\
\hline & & Precipitation & $\cdots$ & 60.4 & 49.6 & 45.4 & 119.9 & 275.3 \\
\hline & \multirow{2}{*}{1989} & ${ }^{90} \mathrm{Sr}$ Deposition & & $0.1^{f}$ & $0.0^{\mathrm{g}}$ & $0.0^{\mathrm{g}}$ & $0.1^{\mathrm{e}}$ & 0.3 \\
\hline & & Precipitation & $\ldots$ & 104.8 & 56.4 & 21.2 & 101.8 & 284.2 \\
\hline & \multirow{2}{*}{1990} & ${ }^{90}$ Sr Deposition & & $0.0^{\mathrm{g}}$ & $0.0^{\mathrm{g}}$ & $0.1^{e}$ & $0.1^{\mathrm{e}}$ & 0.2 \\
\hline & & Precipitation & $\ldots \ldots$ & 50.3 & 57.8 & 28.7 & 69.7 & 206.4 \\
\hline \multirow{8}{*}{ 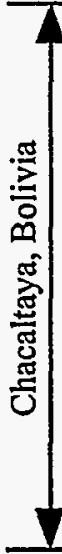 } & \multirow{2}{*}{1987} & ${ }^{90} \mathrm{Sr}$ Deposition & & $0.0^{\mathrm{e}}$ & - & - & $0.0^{f}$ & 0.0 \\
\hline & & Precipitation & $\ldots$ & 27.9 & 2.6 & 3.9 & 19.3 & 53.7 \\
\hline & \multirow{2}{*}{1988} & ${ }^{90} \mathrm{Sr}$ Deposition & & $0.0^{\mathrm{g}}$ & $0.0^{f}$ & $0.1^{\mathrm{g}}$ & - & 0.1 \\
\hline & & Precipitation & $\ldots$ & - & - & - & - & - \\
\hline & \multirow{2}{*}{1989} & ${ }^{90} \mathrm{Sr}$ Deposition & & $0.0^{\mathrm{g}}$ & $0.0^{\mathrm{f}}$ & $0.2^{\mathrm{f}}$ & $0.0^{\mathrm{g}}$ & 0.2 \\
\hline & & Precipitation & $\cdots$ & 0.8 & 102.8 & 34.5 & 15.0 & 153.2 \\
\hline & \multirow{2}{*}{1990} & ${ }^{90} \mathrm{Sr}$ Deposition & & $0.0^{\mathrm{g}}$ & $0.0^{\mathrm{g}}$ & $0.0^{\mathrm{g}}$ & $0.0^{h}$ & 0.0 \\
\hline & & Precipitation & . . & 1.7 & 69.0 & 42.0 & 0.6 & 113.4 \\
\hline \multirow{8}{*}{ 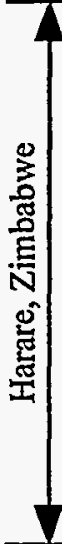 } & \multirow{2}{*}{1987} & ${ }^{90} \mathrm{Sr}$ Deposition & & $0.1^{\mathrm{e}}$ & $0.0^{\mathrm{g}}$ & $0.0^{\mathrm{g}}$ & $0.2^{\mathrm{e}}$ & 0.2 \\
\hline & & Precipitation & . & 31.6 & 0.0 & 0.2 & 39.3 & 71.1 \\
\hline & \multirow{2}{*}{1988} & ${ }^{90} \mathrm{Sr}$ Deposition & & $0.1^{\mathrm{e}}$ & $0.0^{\mathrm{g}}$ & $0.1^{\mathrm{e}}$ & $0.1^{\mathrm{g}}$ & 0.3 \\
\hline & & Precipitation & $\cdots$ & 59.8 & 5.7 & 0.1 & 26.4 & 92.1 \\
\hline & \multirow{2}{*}{1989} & ${ }^{90} \mathrm{Sr}$ Deposition & & $0.0^{\mathrm{g}}$ & $0.1^{e}$ & $0.0^{\mathrm{g}}$ & $0.0^{\mathrm{g}}$ & 0.1 \\
\hline & & Precipitation & - & 49.3 & 0.9 & 0.8 & 20.0 & 71.0 \\
\hline & \multirow{2}{*}{1990} & ${ }^{90} \mathrm{Sr}$ Deposition & & $0.0^{\mathrm{g}}$ & $0.0^{\mathrm{g}}$ & $0.1^{e}$ & $0.0^{f}$ & 0.1 \\
\hline & & Precipitation & $\ldots$ & 27.3 & 6.9 & 0.0 & 23.4 & 57.6 \\
\hline
\end{tabular}


TABLE 4 (Cont'd)

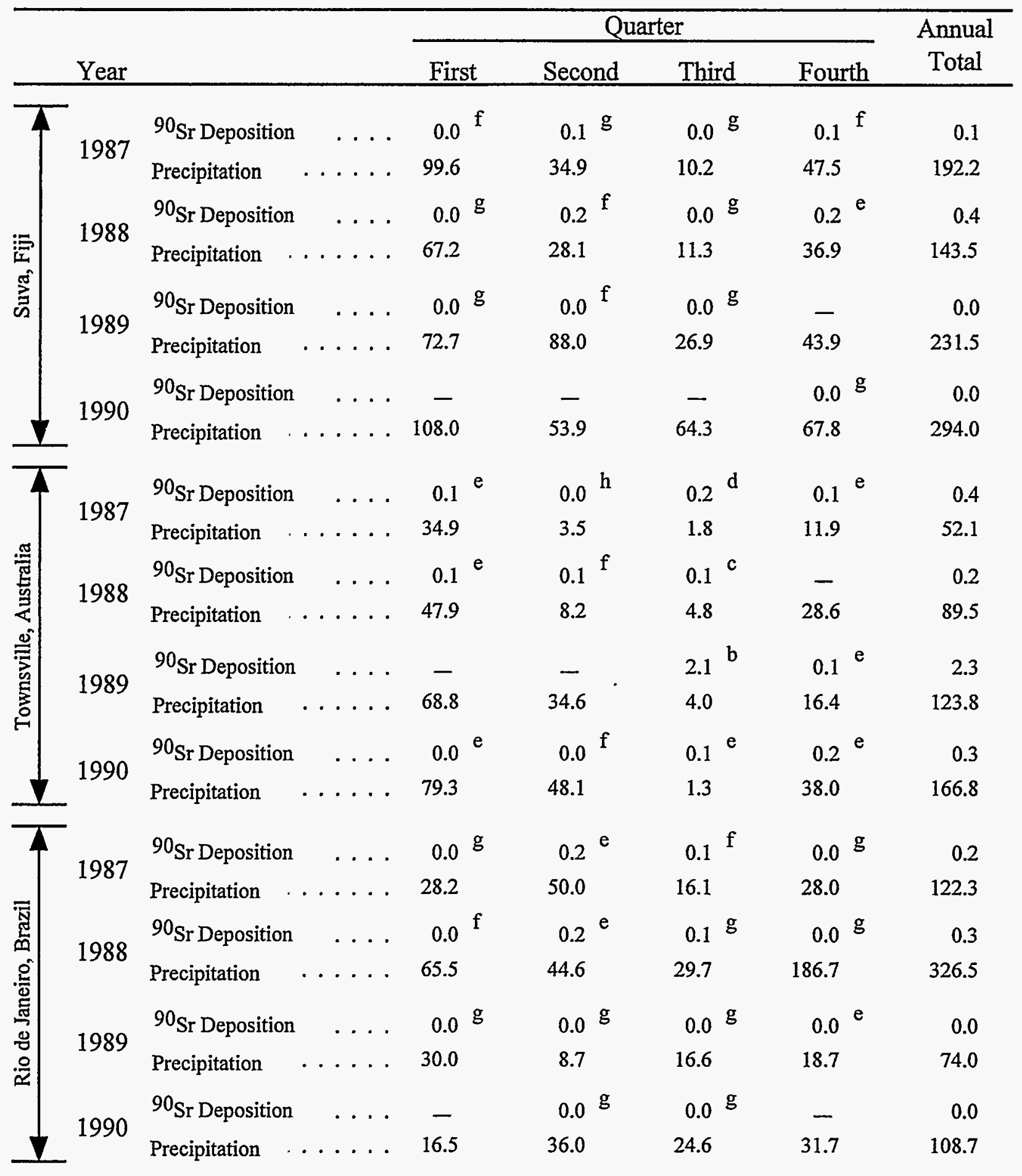


TABLE 4 (Cont'd)

\begin{tabular}{|c|c|c|c|c|c|c|c|c|}
\hline \multirow{2}{*}{\multicolumn{2}{|c|}{ Year }} & & & \multicolumn{4}{|c|}{ Quarter } & \multirow{2}{*}{$\begin{array}{c}\text { Annua } \\
\text { Total }\end{array}$} \\
\hline & & & & First & Second & Third & Fourth & \\
\hline \multirow{8}{*}{ 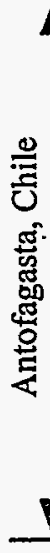 } & \multirow{2}{*}{1987} & ${ }^{90} \mathrm{Sr}$ Deposition & $\ldots$ & - & $0.3^{\mathrm{d}}$ & $0.0^{\mathrm{g}}$ & $0.2^{\mathrm{e}}$ & 0.5 \\
\hline & & Precipitation & $\ldots$ & 0.0 & 0.0 & 0.8 & 0.0 & 0.8 \\
\hline & \multirow{2}{*}{1988} & ${ }^{90} \mathrm{Sr}$ Deposition & $\ldots$ & $0.1^{f}$ & $0.5^{\mathrm{e}}$ & $0.1^{\mathrm{e}}$ & $0.2^{\mathrm{e}}$ & 0.8 \\
\hline & & Precipitation & $\ldots$ & 0.0 & 0.0 & 0.0 & 0.0 & 0.0 \\
\hline & \multirow{2}{*}{1989} & ${ }^{90}$ Sr Deposition & . . & $0.0^{\mathrm{g}}$ & $0.0^{\mathrm{g}}$ & $0.0^{\mathrm{h}}$ & $0.0^{\mathrm{g}}$ & 0.0 \\
\hline & & Precipitation & $\ldots$ & 0.0 & 0.0 & 0.0 & 0.0 & 0.0 \\
\hline & 1000 & ${ }^{90} \mathrm{Sr}$ Deposition & $\ldots$ & $0.0^{\mathrm{g}}$ & $0.0^{\mathrm{g}}$ & $0.0^{\mathrm{g}}$ & $0.1^{\mathrm{e}}$ & 0.1 \\
\hline & טכנו & Precipitation & $\ldots$ & 0.0 & 0.0 & 0.0 & 0.0 & 0.0 \\
\hline \multirow{8}{*}{ 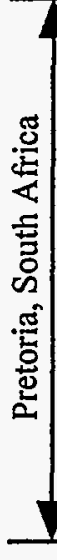 } & \multirow{2}{*}{1987} & ${ }^{90} \mathrm{Sr}$ Deposition & $\ldots$ & $0.1^{\mathrm{d}}$ & $0.0^{\mathrm{g}}$ & $0.0^{\mathrm{g}}$ & $0.1^{\mathrm{e}}$ & 0.3 \\
\hline & & Precipitation & $\cdots$ & 38.5 & 4.7 & 3.4 & 24.3 & 70.9 \\
\hline & \multirow{2}{*}{1988} & ${ }^{90} \mathrm{Sr}$ Deposition & . & $0.5^{\mathrm{d}}$ & $0.0^{f}$ & $0.1^{\mathrm{e}}$ & $0.0^{\mathrm{g}}$ & 0.6 \\
\hline & & Precipitation & $\cdots$ & 24.4 & 1.1 & 3.4 & 20.8 & 49.6 \\
\hline & \multirow{2}{*}{1989} & ${ }^{90} \mathrm{Sr}$ Deposition & & $0.0^{\mathrm{g}}$ & $0.0^{\mathrm{g}}$ & $0.0^{\mathrm{f}}$ & $0.0^{\mathrm{f}}$ & 0.0 \\
\hline & & Precipitation & $\cdots$ & 19.6 & 13.0 & 0.6 & 3.0 & 36.2 \\
\hline & \multirow{2}{*}{1990} & ${ }^{90} \mathrm{Sr}$ Deposition & & $0.0^{\mathrm{g}}$ & $0.0^{\mathrm{f}}$ & $0.2^{\mathrm{d}}$ & $0.1^{\mathrm{e}}$ & 0.2 \\
\hline & & Precipitation & $\ldots$ & 8.5 & 0.5 & 0.8 & 8.2 & 18.0 \\
\hline \multirow{8}{*}{  } & \multirow{2}{*}{1987} & ${ }^{90} \mathrm{Sr}$.Deposition & & $0.0^{\mathrm{e}}$ & $0.0^{\mathrm{e}}$ & $0.1^{f}$ & $0.1^{\mathrm{g}}$ & 0.2 \\
\hline & & Precipitation & $\cdots$ & 13.8 & 41.2 & 19.3 & 5.7 & 80.0 \\
\hline & \multirow{2}{*}{1988} & ${ }^{90} \mathrm{Sr}$ Deposition & & $0.1^{\mathrm{f}}$ & $0.1^{f}$ & $0.0^{\mathrm{e}}$ & $0.0^{h}$ & 0.2 \\
\hline & & Precipitation & $\cdot$ & 32.0 & 20.7 & 24.9 & 12.8 & 90.3 \\
\hline & \multirow{2}{*}{1989} & ${ }^{90} \mathrm{Sr}$ Deposition & & $0.0^{g}$ & $0.0^{\mathrm{g}}$ & $0.2^{f}$ & $0.0^{\mathrm{g}}$ & 0.2 \\
\hline & & Precipitation & $\ldots$ & 28.7 & 42.5 & 24.7 & 25.9 & 121.7 \\
\hline & \multirow{2}{*}{1990} & ${ }^{90} \mathrm{Sr}$ Deposition & & $0.0^{\mathrm{g}}$ & $0.0^{\mathrm{g}}$ & $0.0^{\mathrm{g}}$ & $0.1^{\mathrm{e}}$ & 0.1 \\
\hline & & Precipitation & $\ldots$ & 32.8 & 43.8 & 34.7 & 11.0 & 122.3 \\
\hline
\end{tabular}


TABLE 4 (Cont'd)

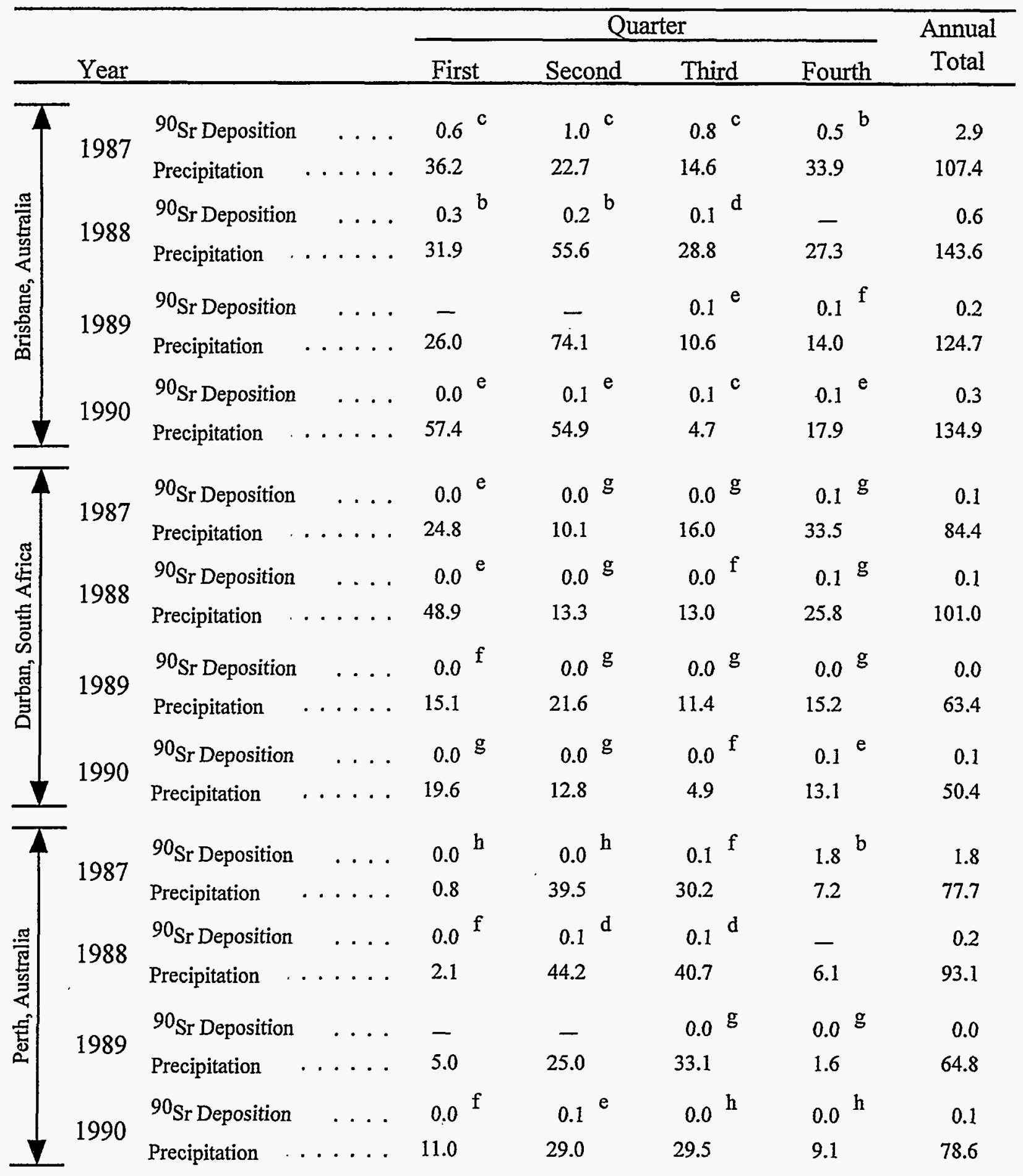


TABLE 4 (Cont'd)

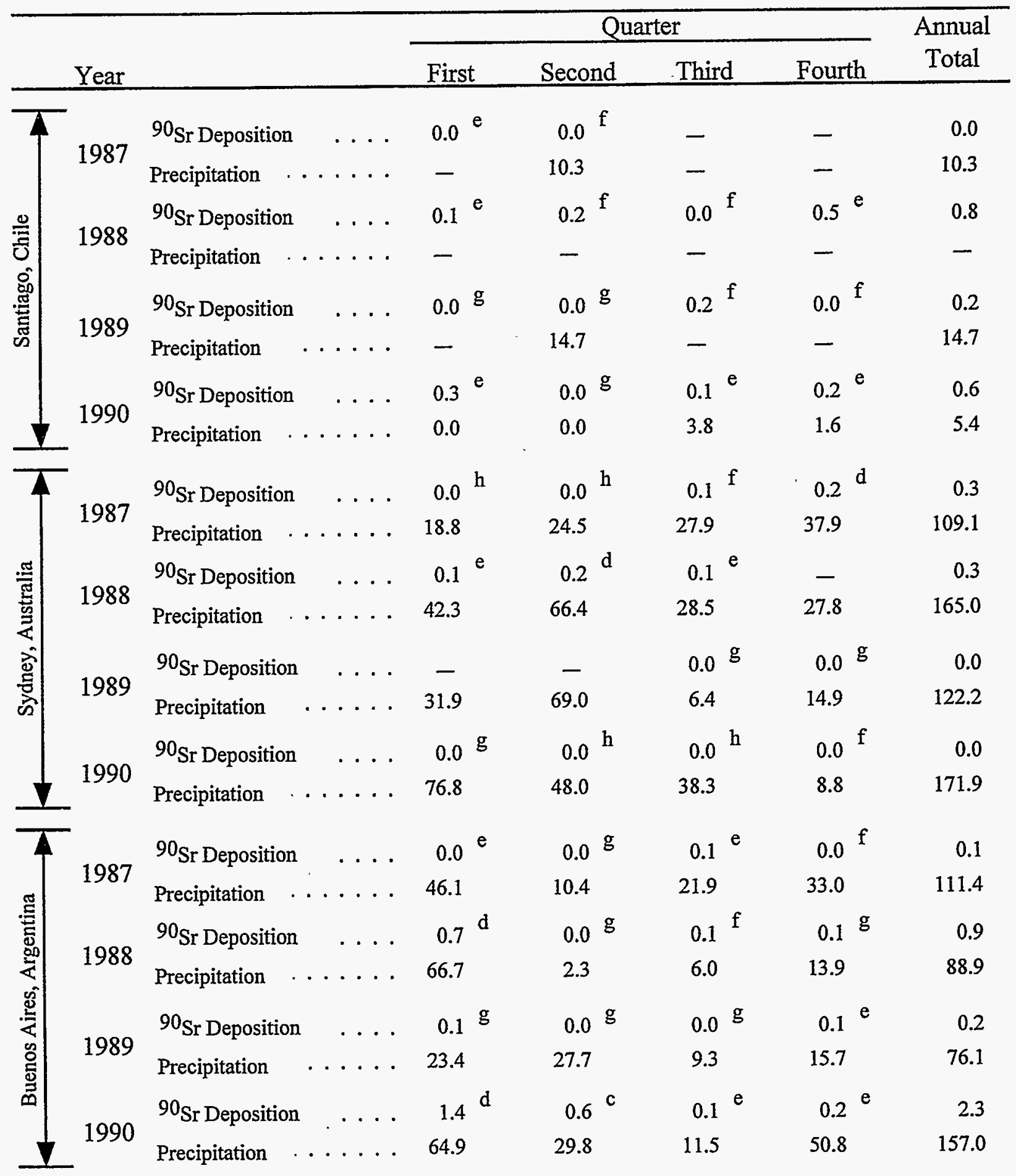


TABLE 4 (Cont'd)




TABLE 4 (Cont'd)

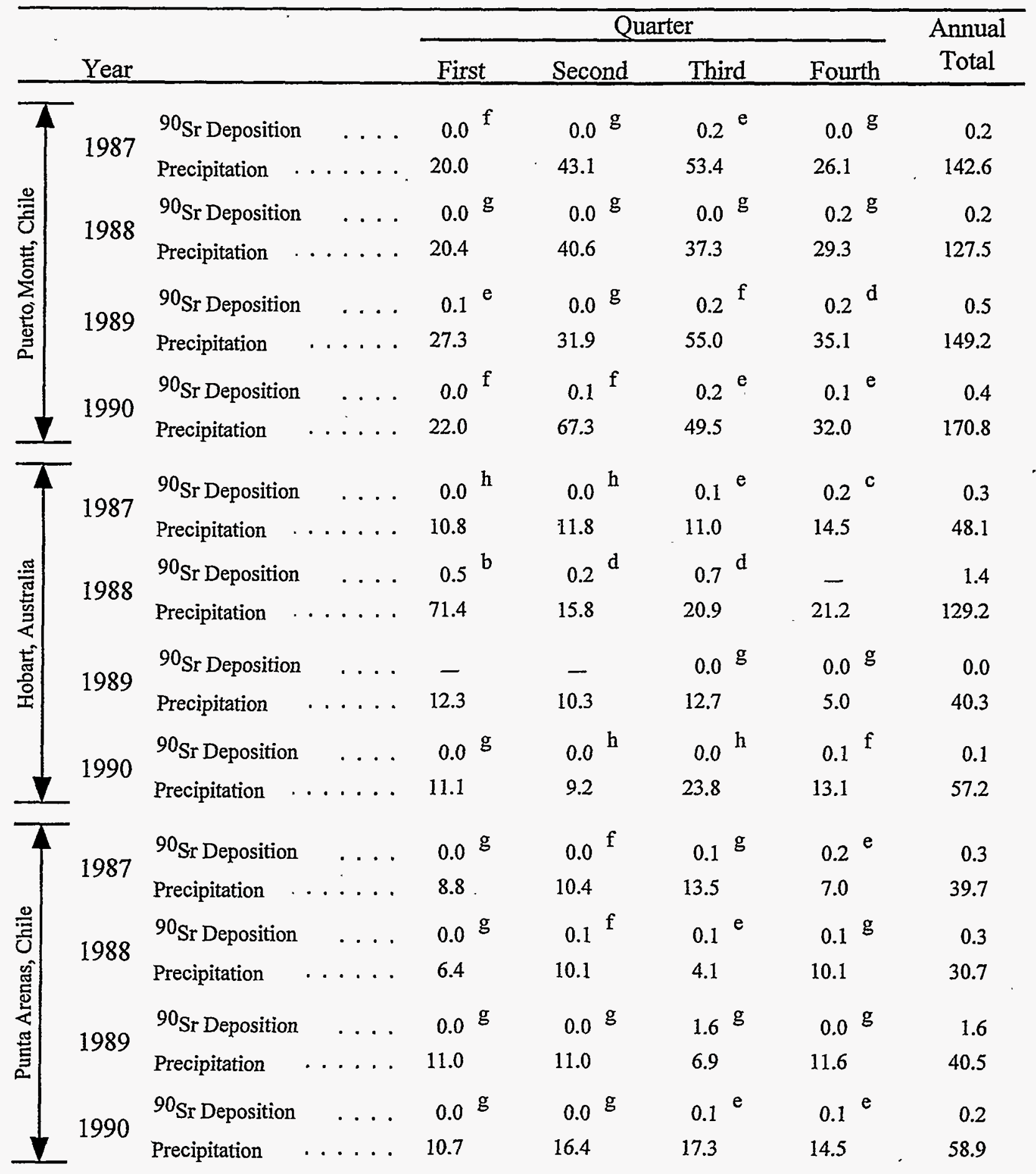


TABLE 4 (Cont'd)

\begin{tabular}{|c|c|c|c|c|c|c|c|}
\hline & & & & & & & Annual \\
\hline & Year & & First & Second & Third & Fourth & Total \\
\hline & & ${ }^{90} \mathrm{Sr}$ Deposition & $0.1^{\mathrm{f}}$ & $0.0^{\mathrm{e}}$ & $0.2^{f}$ & $0.1^{\mathrm{g}}$ & 0.4 \\
\hline & 1901 & Precipitation $\ldots \ldots$ & 17.4 & 13.8 & 3.9 & 12.0 & 47.1 \\
\hline$\stackrel{0}{=}$ & 1000 & ${ }^{90} \mathrm{Sr}$ Deposition & $0.0^{\mathrm{g}}$ & $0.1^{f}$ & $0.1^{f}$ & $0.1^{\mathrm{e}}$ & 0.3 \\
\hline$\tilde{U}$ & 1980 & Precipitation $\ldots \ldots$ & 9.5 & 14.9 & 3.8 & 9.0 & 37.2 \\
\hline : & 1000 & ${ }^{90} \mathrm{Sr}$ Deposition & $0.0^{f}$ & $0.0^{\mathrm{g}}$ & $0.2^{\mathrm{g}}$ & $0.1^{e}$ & 0.3 \\
\hline E & 1989 & Precipitation & 20.9 & 13.4 & 18.2 & 20.3 & 72.7 \\
\hline & & ${ }^{90} \mathrm{Sr}$ Deposition & $0.0^{\mathrm{g}}$ & $0.0^{\mathrm{g}}$ & $0.0^{\mathrm{g}}$ & $0.1^{e}$ & 0.1 \\
\hline & 1990 & Precipitation & 24.8 & 24.9 & 18.5 & 23.8 & 91.9 \\
\hline
\end{tabular}


TABLE 5

COMPARISON OF ESTIMATES OF ${ }^{90} \mathrm{Sr}$ DEPOSITION MADE BY EML AND UKAEA

\begin{tabular}{|c|c|c|c|c|}
\hline \multirow{2}{*}{ Year } & \multicolumn{2}{|c|}{$\begin{array}{l}\text { Annual Deposition } \\
\left(\mathrm{PBq}{ }^{90} \mathrm{Sr}\right)\end{array}$} & \multicolumn{2}{|c|}{$\begin{array}{c}\text { Cumulative Deposit } \\
\left(\mathrm{PBq}{ }^{90} \mathrm{Sr}\right)\end{array}$} \\
\hline & EML & UKAEA & EML & UKAEA \\
\hline 1958 & 32.6 & 31 & 115 & 110 \\
\hline 1959 & 45.9 & 54 & 159 & 158 \\
\hline 1960 & 15.9 & 15 & 170 & 170 \\
\hline 1961 & 19.2 & 21 & 185 & 190 \\
\hline 1962 & 63.3 & 75 & 244 & 260 \\
\hline 1963 & 108.4 & 107 & 344 & 360 \\
\hline 1964 & 77.0 & 81 & 411 & 430 \\
\hline 1965 & 41.8 & 38 & 444 & 460 \\
\hline 1966 & 20.0 & 19 & 451 & 460 \\
\hline 1967 & 10.4 & 10 & 451 & 460 \\
\hline 1968 & 11.1 & 11 & 448 & 460 \\
\hline 1969 & 10.7 & 10 & 451 & 460 \\
\hline 1970 & 12.6 & 8 & 451 & 460 \\
\hline 1971 & 12.6 & 9 & 451 & 460 \\
\hline 1972 & 6.7 & 6 & 448 & 450 \\
\hline 1973 & 2.3 & 5 & 440 & 440 \\
\hline 1974 & 5.9 & 6 & 433 & 440 \\
\hline 1975 & 3.4 & 6 & 426 & 430 \\
\hline 1976 & 1.8 & 2.5 & 418 & 430 \\
\hline 1977 & 3.8 & 4 & 411 & 420 \\
\hline 1978 & 4.4 & 4.5 & 407 & 410 \\
\hline 1979 & 1.5 & 2.5 & 400 & 400 \\
\hline 1980 & 0.9 & 2 & 392 & 400 \\
\hline 1981 & 1.9 & $\sim 3$ & 381 & 390 \\
\hline 1982 & 0.7 & $<2.5$ & 374 & 380 \\
\hline 1983 & 0.5 & $<3$ & 366 & 370 \\
\hline 1984 & 0.4 & $<2$ & 357 & 360 \\
\hline 1985 & 0.2 & $<2$ & 349 & 350 \\
\hline 1986 & 1.7 & $<3$ & 343 & 340 \\
\hline 1987 & 0.3 & $<2$ & 336 & 335 \\
\hline 1988 & 0.2 & $<2$ & 326 & 325 \\
\hline 1989 & 0.2 & $<2$ & 319 & 319 \\
\hline 1990 & 0.1 & $<2$ & 311 & 312 \\
\hline
\end{tabular}


TABLE 6

AVERAGE ${ }^{90} \mathrm{Sr}$ DEPOSITS IN $10^{\circ}$ LATITUDE BANDS DURING $1987\left(\mathrm{~Bq} \mathrm{~m}^{-2}\right)$

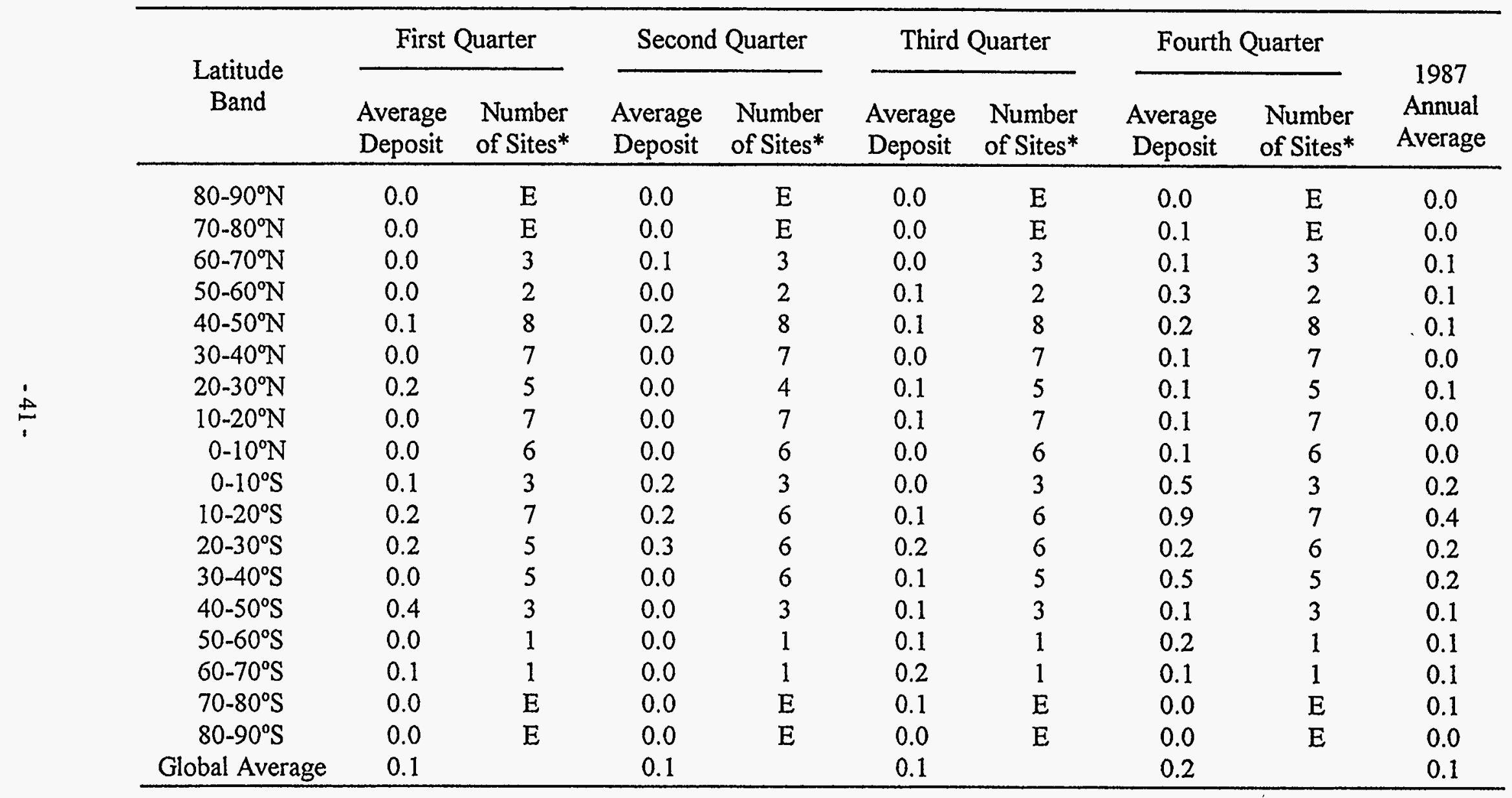

*E indicates that no sampling sites are in the latitude band, and the data was obtained by extrapolating the results to a value of zero at the poles. 
TABLE 7

AVERAGE ${ }^{90} \mathrm{Sr}$ DEPOSITS IN $10^{\circ}$ LATITUDE BANDS DURING $1988\left(\mathrm{~Bq} \mathrm{~m}^{-2}\right)$

\begin{tabular}{|c|c|c|c|c|c|c|c|c|c|}
\hline \multirow[b]{2}{*}{$\begin{array}{l}\text { Latitude } \\
\text { Band }\end{array}$} & \multicolumn{2}{|c|}{ First Quarter } & \multicolumn{2}{|c|}{ Second Quarter } & \multicolumn{2}{|c|}{ Third Quarter } & \multicolumn{2}{|c|}{ Fourth Quarter } & \multirow{2}{*}{$\begin{array}{c}1988 \\
\text { Annual } \\
\text { Average }\end{array}$} \\
\hline & $\begin{array}{l}\text { Average } \\
\text { Deposit }\end{array}$ & $\begin{array}{l}\text { Number } \\
\text { of Sites* }\end{array}$ & $\begin{array}{l}\text { Average } \\
\text { Deposit }\end{array}$ & $\begin{array}{l}\text { Number } \\
\text { of Sites* }\end{array}$ & $\begin{array}{l}\text { Average } \\
\text { Deposit }\end{array}$ & $\begin{array}{l}\text { Number } \\
\text { of Sites* }\end{array}$ & $\begin{array}{c}\text { Average } \\
\text { Deposit }\end{array}$ & $\begin{array}{l}\text { Number } \\
\text { of Sites* }\end{array}$ & \\
\hline $80-90^{\circ} \mathrm{N}$ & 0.0 & $E$ & 0.0 & $\mathrm{E}$ & 0.0 & $E$ & 0.0 & $\mathrm{E}$ & 0.0 \\
\hline $70-80^{\circ} \mathrm{N}$ & 0.1 & $E$ & 0.0 & $\mathrm{E}$ & 0.1 & $\mathrm{E}$ & 0.0 & $\mathrm{E}$ & 0.1 \\
\hline $60-70^{\circ} \mathrm{N}$ & 0.2 & 3 & 0.0 & 3 & 0.1 & 3 & 0.0 & 3 & 0.1 \\
\hline $50-60^{\circ} \mathrm{N}$ & 0.1 & 2 & 0.1 & 2 & 0.1 & 2 & 0.1 & 2 & 0.1 \\
\hline $40-50^{\circ} \mathrm{N}$ & 0.2 & 8 & 0.1 & 8 & 0.1 & 8 & 0.1 & 8 & 0.1 \\
\hline $30-40 \mathrm{~N}$ & 0.1 & 7 & 0.0 & 6 & 0.1 & 6 & 0.1 & 6 & 0.1 \\
\hline $20-30^{\circ} \mathrm{N}$ & 0.1 & 5 & 0.0 & 5 & 0.0 & 5 & 0.1 & 5 & 0.1 \\
\hline $10-20^{\circ} \mathrm{N}$ & 0.0 & 7 & 0.0 & 7 & 0.0 & 7 & 0.1 & 7 & 0.0 \\
\hline $0-10^{\circ} \mathrm{N}$ & 0.0 & 6 & 0.1 & 6 & 0.0 & 6 & 0.1 & 6 & 0.1 \\
\hline $0-10^{\circ} \mathrm{S}$ & 0.0 & 3 & 0.1 & 3 & 0.1 & 3 & 0.2 & 3 & 0.1 \\
\hline $10-20^{\circ} \mathrm{S}$ & 0.3 & 7 & 0.2 & 7 & 0.1 & 4 & 0.1 & 4 & 0.2 \\
\hline $20-30^{\circ} \mathrm{S}$ & 0.2 & 6 & 0.2 & 6 & 0.1 & 4 & 0.1 & 4 & 0.1 \\
\hline $30-40^{\circ} \mathrm{S}$ & 0.2 & 5 & 0.1 & 6 & 0.1 & 2 & 0.3 & 2 & 0.2 \\
\hline $40-50^{\circ} \mathrm{S}$ & 0.2 & 3 & 0.1 & 3 & 0.3 & 2 & 0.1 & 2 & 0.2 \\
\hline $50-60^{\circ} \mathrm{S}$ & 0.0 & 1 & 0.1 & 1 & 0.1 & 1 & 0.1 & 1 & 0.1 \\
\hline $60-70^{\circ} \mathrm{S}$ & 0.0 & 1 & 0.1 & 1 & 0.1 & 1 & 0.1 & 1 & 0.1 \\
\hline $70-80^{\circ} \mathrm{S}$ & 0.0 & $\mathrm{E}$ & 0.0 & $\mathrm{E}$ & 0.0 & $\mathrm{E}$ & 0.1 & $E$ & 0.0 \\
\hline $80-90^{\circ} \mathrm{S}$ & 0.0 & $\mathrm{E}$ & 0.0 & $\mathrm{E}$ & 0.0 & $\mathrm{E}$ & 0.0 & $\mathrm{E}$ & 0.0 \\
\hline Global Average & 0.1 & & 0.1 & & 0.1 & & 0.1 & & 0.1 \\
\hline
\end{tabular}

*E indicates that no sampling sites are in the latitude band, and the data was obtained by extrapolating the results to a value of zero at the poles. 
TABLE 8

AVERAGE ${ }^{90} \mathrm{Sr}$ DEPOSITS IN $10^{\circ}$ LATITUDE BANDS DURING $1989\left(\mathrm{~Bq} \mathrm{~m}^{-2}\right)$

\begin{tabular}{|c|c|c|c|c|c|c|c|c|c|}
\hline \multirow[b]{2}{*}{$\begin{array}{c}\text { Latitude } \\
\text { Band }\end{array}$} & \multicolumn{2}{|c|}{ First Quarter } & \multicolumn{2}{|c|}{ Second Quarter } & \multicolumn{2}{|c|}{ Third Quarter } & \multicolumn{2}{|c|}{ Fourth Quarter } & \multirow{2}{*}{$\begin{array}{c}1989 \\
\text { Annual } \\
\text { Average } \\
\end{array}$} \\
\hline & $\begin{array}{c}\text { Average } \\
\text { Deposit }\end{array}$ & $\begin{array}{l}\text { Number } \\
\text { of Sites* }\end{array}$ & $\begin{array}{l}\text { Average } \\
\text { Deposit }\end{array}$ & $\begin{array}{l}\text { Number } \\
\text { of Sites* }\end{array}$ & $\begin{array}{l}\text { Average } \\
\text { Deposit }\end{array}$ & $\begin{array}{l}\text { Number } \\
\text { of Sites* }\end{array}$ & $\begin{array}{c}\text { Average } \\
\text { Deposit }\end{array}$ & $\begin{array}{l}\text { Number } \\
\text { of Sites* }\end{array}$ & \\
\hline $80-90^{\circ} \mathrm{N}$ & 0.0 & $E$ & 0.0 & $\mathrm{E}$ & 0.0 & $\mathrm{E}$ & 0.0 & $E$ & 0.0 \\
\hline $70-80^{\circ} \mathrm{N}$ & 0.1 & $\mathrm{E}$ & 0.0 & $E$ & 0.1 & $\mathrm{E}$ & 0.0 & $\mathrm{E}$ & 0.0 \\
\hline $60-70^{\circ} \mathrm{N}$ & 0.1 & 2 & 0.0 & 3 & 0.1 & 3 & 0.0 & 3 & 0.1 \\
\hline $50-60^{\circ} \mathrm{N}$ & 0.1 & 2 & 0.0 & 2 & 0.2 & 2 & 0.0 & 2 & 0.1 \\
\hline $40-50^{\circ} \mathrm{N}$ & 0.1 & 7 & 0.1 & 7 & 0.1 & 7 & 0.1 & 7 & 0.1 \\
\hline $30-40^{\circ} \mathrm{N}$ & 0.1 & 6 & 0.0 & 7 & 0.0 & 6 & 0.0 & 6 & 0.0 \\
\hline $20-30^{\circ} \mathrm{N}$ & 0.1 & 5 & 0.0 & 5 & 0.0 & 4 & 0.1 & 4 & 0.1 \\
\hline $10-20^{\circ} \mathrm{N}$ & 0.0 & 6 & 0.0 & 6 & 0.2 & 6 & 0.0 & 7 & 0.1 \\
\hline $0-10^{\circ} \mathrm{N}$ & 0.0 & 7 & 0.1 & 7 & 0.1 & 7 & 0.0 & 8 & 0.1 \\
\hline $0-10^{\circ} \mathrm{S}$ & 0.0 & 3 & 0.0 & 3 & 0.0 & 3 & 0.3 & 2 & 0.1 \\
\hline $10-20^{\circ} \mathrm{S}$ & 0.0 & 5 & 0.0 & 7 & 1.4 & 7 & 0.2 & 6 & 0.4 \\
\hline $20-30^{\circ} \mathrm{S}$ & 0.0 & 5 & 0.0 & 5 & 0.0 & 6 & 0.0 & 6 & 0.0 \\
\hline $30-40^{\circ} \mathrm{S}$ & 0.0 & 2 & 0.0 & 2 & 0.1 & 6 & 0.0 & 6 & 0.1 \\
\hline $40-50^{\circ} \mathrm{S}$ & 0.0 & 2 & 0.0 & 2 & 0.1 & 3 & 0.1 & 3 & 0.1 \\
\hline $50-60^{\circ} \mathrm{S}$ & 0.0 & 1 & 0.0 & 1 & 1.6 & 1 & 0.0 & 1 & 0.4 \\
\hline $60-70^{\circ} \mathrm{S}$ & 0.0 & 1 & 0.0 & 1 & 0.2 & 1 & 0.1 & 1 & 0.1 \\
\hline $70-80^{\circ} \mathrm{S}$ & 0.0 & $\mathrm{E}$ & 0.0 & $\mathrm{E}$ & 0.1 & $\mathrm{E}$ & 0.1 & $\mathrm{E}$ & 0.0 \\
\hline $80-90^{\circ} \mathrm{S}$ & 0.0 & $\mathrm{E}$ & 0.0 & $\mathrm{E}$ & 0.0 & $\mathrm{E}$ & 0.0 & $\mathrm{E}$ & 0.0 \\
\hline Global Average & 0.0 & & 0.0 & & 0.2 & & 0.1 & & 0.1 \\
\hline
\end{tabular}

*E indicates that no sampling sites are in the latitude band, and the data was obtained by extrapolating the results to a value of zero at the poles. 
TABLE 9

AVERAGE ${ }^{90} \mathrm{Sr}$ DEPOSITS IN $10^{\circ}$ LATITUDE BANDS DURING $1990\left(\mathrm{~Bq} \mathrm{~m}^{-2}\right)$

\begin{tabular}{|c|c|c|c|c|c|c|c|c|c|}
\hline \multirow[b]{2}{*}{$\begin{array}{c}\text { Latitude } \\
\text { Band }\end{array}$} & \multicolumn{2}{|c|}{ First Quarter } & \multicolumn{2}{|c|}{ Second Quarter } & \multicolumn{2}{|c|}{ Third Quarter } & \multicolumn{2}{|c|}{ Fourth Quarter } & \multirow{2}{*}{$\begin{array}{c}1990 \\
\text { Annual } \\
\text { Average }\end{array}$} \\
\hline & $\begin{array}{l}\text { Average } \\
\text { Deposit }\end{array}$ & $\begin{array}{l}\text { Number } \\
\text { of Sites* }\end{array}$ & $\begin{array}{c}\text { Average } \\
\text { Deposit }\end{array}$ & $\begin{array}{l}\text { Number } \\
\text { of Sites* }\end{array}$ & $\begin{array}{l}\text { Average } \\
\text { Deposit } \\
\end{array}$ & $\begin{array}{l}\text { Number } \\
\text { of Sites* }\end{array}$ & $\begin{array}{c}\text { Average } \\
\text { Deposit } \\
\end{array}$ & $\begin{array}{l}\text { Number } \\
\text { of Sites* }\end{array}$ & \\
\hline $80-90^{\circ} \mathrm{N}$ & 0.0 & $E$ & 0.0 & $\mathrm{E}$ & 0.0 & $\mathrm{E}$ & 0.0 & $\mathrm{E}$ & 0.0 \\
\hline $70-80^{\circ} \mathrm{N}$ & 0.0 & $\mathrm{E}$ & 0.0 & $E$ & 0.1 & $\mathrm{E}$ & 0.0 & $\mathrm{E}$ & 0.0 \\
\hline $60-70^{\circ} \mathrm{N}$ & 0.0 & 3 & 0.0 & 3 & 0.1 & 2 & 0.1 & 2 & 0.1 \\
\hline $50-60^{\circ} \mathrm{N}$ & 0.0 & 2 & 0.0 & 2 & 0.1 & 2 & 0.0 & 2 & 0.0 \\
\hline $40-50^{\circ} \mathrm{N}$ & 0.0 & 7 & 0.1 & 8 & 0.1 & 8 & 0.1 & 8 & 0.1 \\
\hline $30-40^{\circ} \mathrm{N}$ & 0.0 & 7 & 0.0 & 7 & 0.0 & 7 & 0.1 & 7 & 0.0 \\
\hline $20-30^{\circ} \mathrm{N}$ & 0.1 & 4 & 0.0 & 4 & 0.0 & 3 & 0.1 & 4 & 0.0 \\
\hline $10-20^{\circ} \mathrm{N}$ & 0.0 & 7 & 0.1 & 7 & 0.1 & 7 & 0.1 & 7 & 0.1 \\
\hline $0-10^{\circ} \mathrm{N}$ & 0.0 & 6 & 0.0 & 6 & 0.0 & 5 & 0.1 & 6 & 0.0 \\
\hline $0-10^{\circ} \mathrm{S}$ & 0.4 & 3 & 0.0 & 3 & 0.3 & 3 & 0.0 & 3 & 0.2 \\
\hline $10-20^{\circ} \mathrm{S}$ & 0.3 & 6 & 0.1 & 6 & 0.1 & 6 & 0.1 & 7 & 0.1 \\
\hline $20-30^{\circ} \mathrm{S}$ & 0.0 & 5 & 0.0 & 6 & 0.1 & 6 & 0.1 & 5 & 0.0 \\
\hline $30-40^{\circ} \mathrm{S}$ & 0.3 & 6 & 0.1 & 6 & 0.0 & 6 & 0.1 & 6 & 0.1 \\
\hline $40-50^{\circ} \mathrm{S}$ & 0.0 & 3 & 0.0 & 3 & 0.1 & 3 & 0.1 & 3 & 0.0 \\
\hline $50-60^{\circ} \mathrm{S}$ & 0.0 & 1 & 0.0 & 1 & 0.1 & 1 & 0.1 & 1 & 0.0 \\
\hline $60-70^{\circ} \mathrm{S}$ & 0.0 & 1 & 0.0 & 1 & 0.0 & 1 & 0.1 & 1 & 0.0 \\
\hline $70-80^{\circ} \mathrm{S}$ & 0.0 & $\mathrm{E}$ & 0.0 & $\mathrm{E}$ & 0.0 & $\mathrm{E}$ & 0.0 & $\mathbf{E}$ & 0.0 \\
\hline $80-90^{\circ} \mathrm{S}$ & 0.0 & $\mathrm{E}$ & 0.0 & $\mathrm{E}$ & 0.0 & $\mathrm{E}$ & 0.0 & $\mathbf{E}$ & 0.0 \\
\hline Global Average & 0.1 & & 0.0 & & 0.1 & & 0.1 & & 0.1 \\
\hline
\end{tabular}

*E indicates that no sampling sites are in the latitude band, and the data was obtained by extrapolating the results to a value of zero at the poles. 
TABLE 10

TOTAL ${ }^{90} \mathrm{Sr}$ DEPOSITS IN $10^{\circ}$ LATITUDE BANDS DURING 1987 (TBq)

\begin{tabular}{|c|c|c|c|c|c|}
\hline $\begin{array}{c}\text { Latitude } \\
\text { Band }\end{array}$ & $\begin{array}{c}\text { First Quarter } \\
\text { Total } \\
\text { Deposit }\end{array}$ & $\begin{array}{c}\text { Second Quarter } \\
\text { Total } \\
\text { Deposit }\end{array}$ & $\begin{array}{c}\text { Third Quarter } \\
\text { Total } \\
\text { Deposit } \\
\end{array}$ & $\begin{array}{c}\text { Fourth Quarter } \\
\text { Total } \\
\text { Deposit }\end{array}$ & $\begin{array}{c}1987 \\
\text { Annual } \\
\text { Total }\end{array}$ \\
\hline $80-90^{\circ} \mathrm{N}$ & 0.0 & 0.0 & 0.0 & 0.1 & 0.1 \\
\hline $70-80^{\circ} \mathrm{N}$ & 0.2 & 0.5 & 0.0 & 0.8 & 1.5 \\
\hline $60-70^{\circ} \mathrm{N}$ & 0.5 & 1.4 & 0.0 & 2.2 & 4.1 \\
\hline $50-60^{\circ} \mathrm{N}$ & 0.2 & 0.0 & 2.4 & 6.6 & 9.2 \\
\hline $40-50^{\circ} \mathrm{N}$ & 3.5 & 5.4 & 2.7 & 5.0 & 16.6 \\
\hline $30-40^{\circ} \mathrm{N}$ & 0.8 & 0.7 & 1.7 & 1.9 & 5.1 \\
\hline $20-30^{\circ} \mathrm{N}$ & 6.6 & 1.9 & 2.9 & 4.4 & 15.8 \\
\hline $10-20^{\circ} \mathrm{N}$ & 0.4 & 1.0 & 3.5 & 3.4 & 8.4 \\
\hline $0.10^{\circ} \mathrm{N}$ & 0.0 & 1.0 & 2.2 & 5.4 & 8.6 \\
\hline $0-10^{\circ} \mathrm{S}$ & 4.0 & 8.6 & 0.8 & 20.4 & 33.9 \\
\hline $10-20^{\circ} \mathrm{S}$ & 8.8 & 8.2 & 4.8 & 40.0 & 61.9 \\
\hline $20-30^{\circ} \mathrm{S}$ & 6.1 & 10.2 & 6.6 & 6.5 & 29.4 \\
\hline $30-40^{\circ} \mathrm{S}$ & 0.9 & 1.7 & 3.1 & 16.6 & 22.3 \\
\hline $40-50^{\circ} \mathrm{S}$ & 12.3 & 0.0 & 2.8 & 3.6 & 18.7 \\
\hline $50-60^{\circ} \mathrm{S}$ & 0.0 & 0.0 & 1.4 & 6.3 & 7.7 \\
\hline $60-70^{\circ} \mathrm{S}$ & 1.1 & 0.0 & 4.1 & 1.5 & 6.7 \\
\hline $70-80^{\circ} \mathrm{S}$ & 0.4 & 0.0 & 1.5 & 0.6 & 2.5 \\
\hline $80-90^{\circ} \mathrm{S}$ & 0.0 & 0.0 & 0.1 & 0.1 & 0.2 \\
\hline Global Total & 45.9 & 40.6 & 40.8 & 125.4 & 252.7 \\
\hline
\end{tabular}


TABLE 11

TOTAL ${ }^{90} \mathrm{Sr}$ DEPOSITS IN $10^{\circ}$ LATITUDE BANDS DURING 1988 (TBq)

\begin{tabular}{|c|c|c|c|c|c|}
\hline $\begin{array}{l}\text { Latitude } \\
\text { Band }\end{array}$ & $\begin{array}{c}\text { First Quarter } \\
\text { Total } \\
\text { Deposit }\end{array}$ & $\begin{array}{c}\text { Second Quarter } \\
\text { Total } \\
\text { Deposit }\end{array}$ & $\begin{array}{c}\text { Third Quarter } \\
\begin{array}{c}\text { Total } \\
\text { Deposit }\end{array}\end{array}$ & $\frac{\text { Fourth Quarter }}{\begin{array}{c}\text { Total } \\
\text { Deposit }\end{array}}$ & $\begin{array}{c}1988 \\
\text { Annual } \\
\text { Total }\end{array}$ \\
\hline $80-90^{\circ} \mathrm{N}$ & 0.0 & 0.0 & 0.0 & 0.0 & 0.0 \\
\hline $70-80^{\circ} \mathrm{N}$ & 1.3 & 0.1 & 1.0 & 0.0 & 2.5 \\
\hline $60-70^{\circ} \mathrm{N}$ & 3.6 & 0.3 & 2.7 & 0.0 & 6.7 \\
\hline $50-60^{\circ} \mathrm{N}$ & 2.8 & 2.4 & 3.1 & 1.7 & 10.1 \\
\hline $40-50^{\circ} \mathrm{N}$ & 5.6 & 2.6 & 3.1 & 3.0 & 14.3 \\
\hline $30-40^{\circ} \mathrm{N}$ & 4.0 & 0.6 & 2.7 & 2.9 & 10.2 \\
\hline $20-30^{\circ} \mathrm{N}$ & 4.4 & 1.9 & 1.6 & 3.8 & 11.7 \\
\hline $10-20^{\circ} \mathrm{N}$ & 2.0 & 0.7 & 1.0 & 4.6 & 8.2 \\
\hline $0-10^{\circ} \mathrm{N}$ & 1.4 & 2.8 & 2.2 & 4.2 & 10.6 \\
\hline $0-10^{\circ} \mathrm{S}$ & 2.0 & 5.1 & 3.0 & 9.9 & 20.0 \\
\hline $10-20^{\circ} \mathrm{S}$ & 11.1 & 6.7 & 3.1 & 5.8 & 26.7 \\
\hline $20-30^{\circ} \mathrm{S}$ & 6.4 & 6.3 & 2.9 & 2.7 & 18.3 \\
\hline $30-40^{\circ} \mathrm{S}$ & 8.6 & 4.0 & 2.0 & 11.9 & 26.6 \\
\hline $40-50^{\circ} \mathrm{S}$ & 4.9 & 2.4 & 8.6 & 4.3 & 20.2 \\
\hline $50-60^{\circ} \mathrm{S}$ & 0.0 & 2.1 & 3.5 & 2.8 & 8.4 \\
\hline $60-70^{\circ} \mathrm{S}$ & 0.0 & 1.5 & 1.5 & 2.6 & 5.7 \\
\hline $70-80^{\circ} \mathrm{S}$ & 0.0 & 0.6 & 0.6 & 0.9 & 2.1 \\
\hline $80-90^{\circ} \mathrm{S}$ & 0.0 & 0.1 & 0.1 & 0.1 & 0.2 \\
\hline Global Total & 58.0 & 40.2 . & 42.9 & 61.3 & 202.5 \\
\hline
\end{tabular}


TABLE 12

TOTAL ${ }^{90} \mathrm{Sr}$ DEPOSITS IN $10^{\circ}$ LATITUDE BANDS DURING 1989 (TBq)

\begin{tabular}{|c|c|c|c|c|c|}
\hline $\begin{array}{l}\text { Latitude } \\
\text { Band }\end{array}$ & $\begin{array}{c}\text { First Quarter } \\
\text { Total } \\
\text { Deposit } \\
\end{array}$ & $\begin{array}{c}\text { Second Quarter } \\
\text { Total } \\
\text { Deposit } \\
\end{array}$ & $\begin{array}{c}\text { Third Quarter } \\
\text { Total } \\
\text { Deposit } \\
\end{array}$ & $\begin{array}{c}\text { Fourth Quarter } \\
\text { Total } \\
\text { Deposit } \\
\end{array}$ & $\begin{array}{c}1989 \\
\text { Annual } \\
\text { Total }\end{array}$ \\
\hline $80-90^{\circ} \mathrm{N}$ & 0.0 & 0.0 & 0.0 & 0.0 & 0.0 \\
\hline $70-80^{\circ} \mathrm{N}$ & 1.0 & 0.3 & 0.7 & 0.2 & 2.3 \\
\hline $60-70^{\circ} \mathrm{N}$ & 2.8 & 0.7 & 2.0 & 0.6 & 6.2 \\
\hline $50-60^{\circ} \mathrm{N}$ & 1.7 & 0.0 & 4.4 & 0.9 & 7.1 \\
\hline $40-50^{\circ} \mathrm{N}$ & 2.3 & 2.2 & 4.4 & 2.8 & 11.7 \\
\hline $30-40^{\circ} \mathrm{N}$ & 2.0 & 0.9 & 0.4 & 1.0 & 4.3 \\
\hline $20-30^{\circ} \mathrm{N}$ & 5.2 & 1.0 & 0.2 & 2.3 & 8.7 \\
\hline $10-20^{\circ} \mathrm{N}$ & 1.6 & 0.9 & 8.0 & 1.1 & 11.6 \\
\hline $0-10^{\circ} \mathrm{N}$ & 0.4 & 4.7 & 5.9 & 0.0 & 10.9 \\
\hline $0-10^{\circ} \mathrm{S}$ & 1.9 & 1.7 & 1.5 & 11.8 & 16.9 \\
\hline $10-20^{\circ} \mathrm{S}$ & 1.1 & 0.7 & 59.8 & 8.7 & 70.4 \\
\hline $20-30^{\circ} \mathrm{S}$ & 0.2 & 0.7 & 1.8 & 0.4 & 3.1 \\
\hline $30-40^{\circ} \mathrm{S}$ & 1.5 & 0.4 & 4.3 & 1.5 & 7.7 \\
\hline $40-50^{\circ} \mathrm{S}$ & 1.4 & 0.0 & 2.5 & 2.4 & 6.3 \\
\hline $50-60^{\circ} \mathrm{S}$ & 0.0 & 0.0 & 41.1 & 0.0 & 41.1 \\
\hline $60-70^{\circ} \mathrm{S}$ & 0.0 & 0.0 & 4.0 & 1.9 & 5.9 \\
\hline $70-80^{\circ} \mathrm{S}$ & 0.0 & 0.0 & 1.5 & 0.7 & 2.2 \\
\hline $80-90^{\circ} \mathrm{S}$ & 0.0 & 0.0 & 0.1 & 0.1 & 0.2 \\
\hline Global Total & 23.2 & 14.2 & 142.5 & 36.6 & 216.5 \\
\hline
\end{tabular}


TABLE 13

TOTAL ${ }^{90} \mathrm{Sr}$ DEPOSITS IN $10^{\circ}$ LATITUDE BANDS DURING 1990 (TBq)

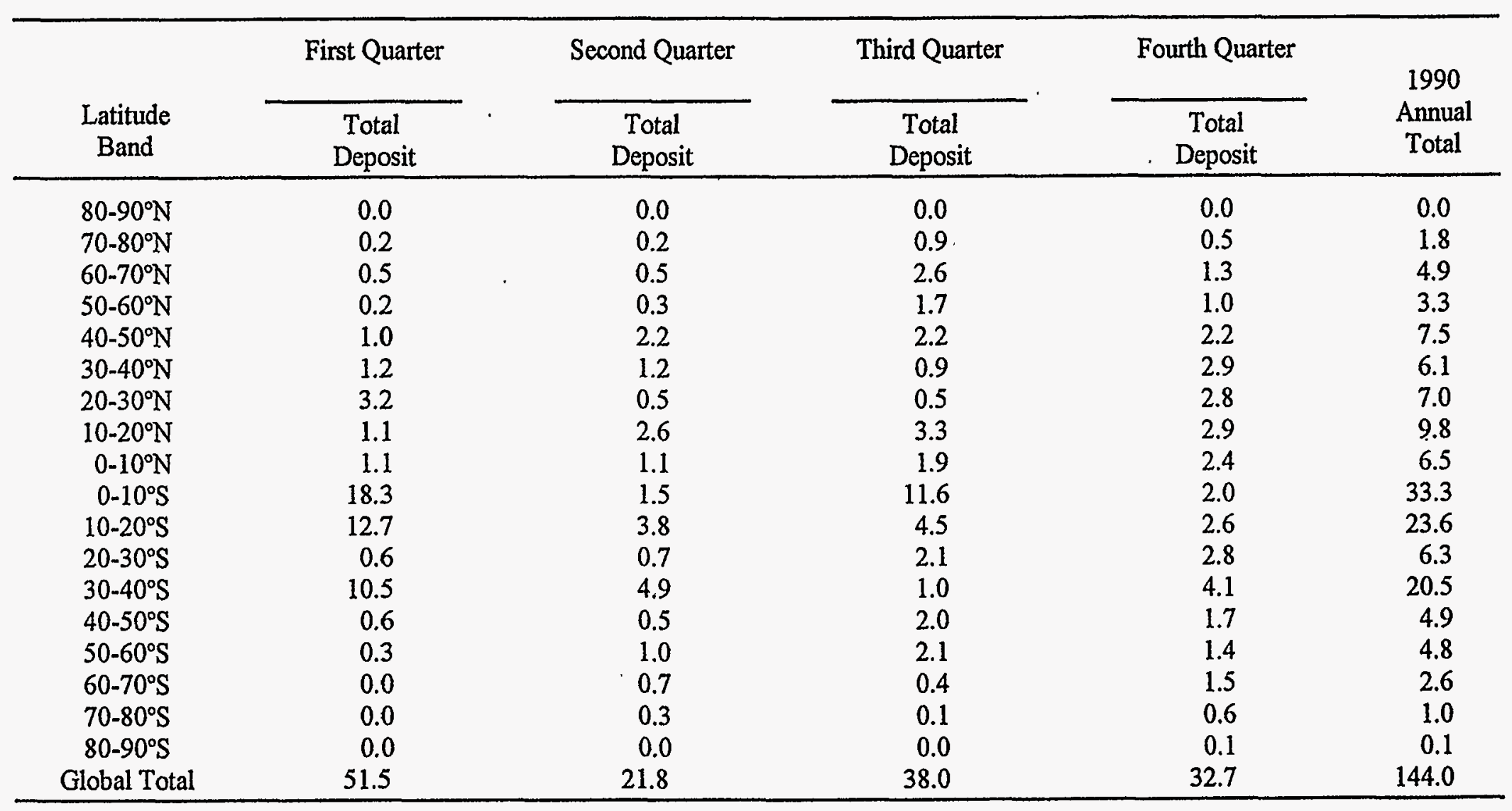


TABLE 14

CUMMULATIVE ${ }^{90} \mathrm{Sr}$ DEPOSITS IN $10^{\circ}$ LATITUDE BANDS DURING 1987 (PBq)

\begin{tabular}{|c|c|c|c|c|}
\hline & First Quarter & Second Quarter & Third Quarter & Fourth Quarter \\
\hline $\begin{array}{l}\text { Latitude } \\
\text { Band }\end{array}$ & $\begin{array}{c}\text { Total } \\
\text { Deposit }\end{array}$ & $\begin{array}{c}\text { Total } \\
\text { Deposit }\end{array}$ & $\begin{array}{c}\text { Total } \\
\text { Deposit }\end{array}$ & $\begin{array}{c}\text { Total } \\
\text { Deposit }\end{array}$ \\
\hline $80-90^{\circ} \mathrm{N}$ & 0.7 & 0.7 & 0.7 & 0.7 \\
\hline $70-80^{\circ} \mathrm{N}$ & 4.8 & 4.7 & 4.7 & 4.7 \\
\hline $60-70^{\circ} \mathrm{N}$ & 18.2 & 18.1 & 18.0 & 17.9 \\
\hline $50-60^{\circ} \mathrm{N}$ & 42.4 & 42.2 & 41.9 & 41.7 \\
\hline $40-50^{\circ} \mathrm{N}$ & 57.8 & 57.4 & 57.1 & 56.7 \\
\hline $30-40^{\circ} \mathrm{N}$ & 48.2 & 47.9 & 47.6 & 47.4 \\
\hline $20-30^{\circ} \mathrm{N}$ & 38.6 & 38.3 & 38.1 & 37.9 \\
\hline $10-20^{\circ} \mathrm{N}$ & 27.1 & 27.0 & 26.8 & 26.7 \\
\hline $0-10^{\circ} \mathrm{N}$ & 19.5 & 19.4 & 19.3 & 19.1 \\
\hline $0-10^{\circ} \mathrm{S}$ & 10.7 & 10.7 & 10.6 & 10.6 \\
\hline $10-20^{\circ} \mathrm{S}$ & 9.9 & 9.8 & 9.7 & 9.7 \\
\hline $20-30^{\circ} \mathrm{S}$ & 15.7 & 15.6 & 15.5 & 15.5 \\
\hline $30-40^{\circ} \mathrm{S}$ & 16.4 & 16.3 & 16.2 & 16.1 \\
\hline $40-50^{\circ} \mathrm{S}$ & 16.4 & 16.3 & 16.2 & 16.1 \\
\hline $50-60^{\circ} \mathrm{S}$ & 8.0 & 7.9 & 7.9 & 7.8 \\
\hline $60-70^{\circ} \mathrm{S}$ & 4.0 & 4.0 & 3.9 & 3.9 \\
\hline $70-80^{\circ} \mathrm{S}$ & 1.5 & 1.5 & 1.5 & 1.5 \\
\hline $80-90^{\circ} \mathrm{S}$ & 0.2 & 0.2 & 0.2 & 0.2 \\
\hline Global Total & 340.0 & 338.0 & 336.0 & 334.1 \\
\hline
\end{tabular}


TABLE 15

CUMMULATIVE ${ }^{90} \mathrm{Sr}$ DEPOSITS IN $10^{\circ}$ LATITUDE BANDS DURING 1988 (PBq)

\begin{tabular}{|c|c|c|c|c|}
\hline & First Quarter & Second Quarter & Third Quarter & Fourth Quarter \\
\hline $\begin{array}{l}\text { Latitude } \\
\text { Band }\end{array}$ & $\begin{array}{c}\text { Total } \\
\text { Deposit }\end{array}$ & $\begin{array}{c}\text { Total } \\
\text { Deposit }\end{array}$ & $\begin{array}{c}\text { Total } \\
\text { Deposit }\end{array}$ & $\begin{array}{c}\text { Total } \\
\text { Deposit }\end{array}$ \\
\hline $80-90^{\circ} \mathrm{N}$ & 0.7 & 0.7 & 0.7 & 0.7 \\
\hline $70.80^{\circ} \mathrm{N}$ & 4.7 & 4.6 & 4.6 & 4.6 \\
\hline $60-70^{\circ} \mathrm{N}$ & 17.8 & 17.7 & 17.6 & 17.4 \\
\hline $50-60^{\circ} \mathrm{N}$ & 41.4 & 41.2 & 41.0 & 40.7 \\
\hline $40-50^{\circ} \mathrm{N}$ & 56.4 & 56.1 & 55.7 & 55.4 \\
\hline $30-40^{\circ} \mathrm{N}$ & 47.1 & 46.8 & 46.5 & 46.2 \\
\hline $20-30^{\circ} \mathrm{N}$ & 37.7 & 37.4 & 37.2 & 37.0 \\
\hline $10-20^{\circ} \mathrm{N}$ & 26.5 & 26.3 & 26.2 & 26.0 \\
\hline $0-10^{\circ} \mathrm{N}$ & 19.0 & 18.9 & 18.8 & 18.7 \\
\hline $0-10^{\circ} \mathrm{S}$ & 10.5 & 10.5 & 10.4 & 10.3 \\
\hline $10-20^{\circ} \mathrm{S}$ & 9.7 & 9.6 & 9.6 & 9.5 \\
\hline $20-30^{\circ} \mathrm{S}$ & 15.4 & 15.3 & 15.2 & 15.1 \\
\hline $30-40^{\circ} \mathrm{S}$ & 16.0 & 16.0 & 15.9 & 15.8 \\
\hline $40-50^{\circ} \mathrm{S}$ & 16.0 & 15.9 & 15.9 & 15.8 \\
\hline $50-60^{\circ} \mathrm{S}$ & 7.8 & 7.7 & 7.7 & 7.6 \\
\hline $60-70^{\circ} \mathrm{S}$ & 3.9 & 3.9 & 3.8 & 3.8 \\
\hline $70-80^{\circ} \mathrm{S}$ & 1.5 & 1.4 & 1.4 & 1.4 \\
\hline $80-90^{\circ} \mathrm{S}$ & 0.2 & 0.2 & 0.2 & 0.2 \\
\hline Global Total & 332.2 & 330.2 & 328.3 & 326.4 \\
\hline
\end{tabular}


TABLE 16

CUMMULATIVE ${ }^{90} \mathrm{Sr}$ DEPOSITS IN 10 LATITUDE BANDS DURING 1989 (PBq)

\begin{tabular}{|c|c|c|c|c|}
\hline & First Quarter & Second Quarter & Third Quarter & Fourth Quarter \\
\hline $\begin{array}{l}\text { Latitude } \\
\text { Band }\end{array}$ & $\begin{array}{l}\text { Total } \\
\text { Deposit }\end{array}$ & $\begin{array}{c}\text { Total } \\
\text { Deposit }\end{array}$ & $\begin{array}{c}\text { Total } \\
\text { Deposit }\end{array}$ & $\begin{array}{c}\text { Total } \\
\text { Deposit }\end{array}$ \\
\hline $80-90^{\circ} \mathrm{N}$ & 0.7 & 0.7 & 0.7 & 0.7 \\
\hline $70-80^{\circ} \mathrm{N}$ & 4.6 & 4.5 & 4.5 & 4.5 \\
\hline $60-70^{\circ} \mathrm{N}$ & 17.3 & 17.2 & 17.1 & 17.0 \\
\hline $50-60^{\circ} \mathrm{N}$ & 40.5 & 40.2 & 40.0 & 39.8 \\
\hline $40-50^{\circ} \mathrm{N}$ & 55.1 & 54.7 & 54.4 & 54.1 \\
\hline $30-40^{\circ} \mathrm{N}$ & 46.0 & 45.7 & 45.4 & 45.1 \\
\hline $20-30^{\circ} \mathrm{N}$ & 36.8 & 36.6 & 36.3 & 36.1 \\
\hline $10-20^{\circ} \mathrm{N}$ & 25.9 & 25.7 & 25.6 & 25.4 \\
\hline $0-10^{\circ} \mathrm{N}$ & 18.6 & 18.5 & 18.4 & 18.3 \\
\hline $0-10^{\circ} \mathrm{S}$ & 10.3 & 10.2 & 10.2 & 10.1 \\
\hline $10-20^{\circ} \mathrm{S}$ & 9.5 & 9.4 & 9.4 & 9.4 \\
\hline $20-30^{\circ} \mathrm{S}$ & 15.0 & 14.9 & 14.8 & 14.7 \\
\hline $30-40^{\circ} \mathrm{S}$ & 15.7 & 15.6 & 15.5 & 15.4 \\
\hline $40-50^{\circ} \mathrm{S}$ & 15.7 & 15.6 & 15.5 & 15.4 \\
\hline $50-60^{\circ} \mathrm{S}$ & 7.6 & 7.5 & 7.5 & 7.5 \\
\hline $60-70^{\circ} \mathrm{S}$ & 3.8 & 3.8 & 3.8 & 3.7 \\
\hline $70-80^{\circ} \mathrm{S}$ & 1.4 & 1.4 & 1.4 & 1.4 \\
\hline $80-90^{\circ} \mathrm{S}$ & 0.2 & 0.2 & 0.2 & 0.2 \\
\hline Global Total & 324.4 & 322.5 & 320.7 & 318.8 \\
\hline
\end{tabular}


TABLE 17

CUMMULATIVE ${ }^{90} \mathrm{Sr}$ DEPOSITS IN $10^{\circ}$ LATITUDE BANDS DURING 1990 (PBq)

\begin{tabular}{|c|c|c|c|c|}
\hline & First Quarter & Second Quarter & Third Quarter & Fourth Quarter \\
\hline $\begin{array}{l}\text { Latitude } \\
\text { Band }\end{array}$ & $\begin{array}{l}\text { Total } \\
\text { Deposit }\end{array}$ & $\begin{array}{c}\text { Total } \\
\text { Deposit }\end{array}$ & $\begin{array}{c}\text { Total } \\
\text { Deposit }\end{array}$ & $\begin{array}{c}\text { Total } \\
\text { Deposit }\end{array}$ \\
\hline $80-90^{\circ} \mathrm{N}$ & 0.6 & 0.6 & 0.7 & 0.6 \\
\hline $70-80^{\circ} \mathrm{N}$ & 4.4 & 4.4 & 4.4 & 4.4 \\
\hline $60-70^{\circ} \mathrm{N}$ & 16.9 & 16.8 & 16.7 & 16.6 \\
\hline $50-60^{\circ} \mathrm{N}$ & 39.5 & 39.3 & 39.0 & 38.8 \\
\hline $40-50^{\circ} \mathrm{N}$ & 53.8 & 53.5 & 53.1 & 52.8 \\
\hline $30-40^{\circ} \mathrm{N}$ & 44.9 & 44.6 & 44.3 & 44.1 \\
\hline $20-30^{\circ} \mathrm{N}$ & 35.9 & 35.7 & 35.5 & 35.3 \\
\hline $10-20^{\circ} \mathrm{N}$ & 25.3 & 25.1 & 25.0 & 24.8 \\
\hline $0-10^{\circ} \mathrm{N}$ & 18.2 & 18.1 & 17.9 & 17.8 \\
\hline $0-10^{\circ} \mathrm{S}$ & 10.1 & 10.0 & 10.0 & 9.9 \\
\hline $10-20^{\circ} \mathrm{S}$ & 9.3 & 9.3 & 9.2 & 9.2 \\
\hline $20-30^{\circ} \mathrm{S}$ & 14.7 & 14.6 & 14.5 & 14.4 \\
\hline $30-40^{\circ} \mathrm{S}$ & 15.3 & 15.2 & 15.1 & 15.1 \\
\hline $40-50^{\circ} \mathrm{S}$ & 15.3 & 15.2 & 15.1 & 15.0 \\
\hline $50-60^{\circ} \mathrm{S}$ & 7.5 & 7.4 & 7.4 & 7.3 \\
\hline $60-70^{\circ} \mathrm{S}$ & 3.7 & 3.7 & 3.7 & 3.7 \\
\hline $70-80^{\circ} \mathrm{S}$ & 1.4 & 1.4 & 1.4 & 1.4 \\
\hline $80-90^{\circ} \mathrm{S}$ & 0.2 & 0.2 & 0.2 & 0.2 \\
\hline Global Total & 317.0 & 315.1 & 313.3 & 311.4 \\
\hline
\end{tabular}


TABLE 18

ANNUAL FISSION YIELDS OF ATMOSPHERIC WEAPONS TESTS AND ${ }^{90} \mathrm{Sr}$ DEPOSITION FOR THE NORTHERN AND SOUTHERN HEMISPHERES

\begin{tabular}{|c|c|c|c|c|}
\hline \multirow[b]{2}{*}{ Year } & \multicolumn{2}{|c|}{ Northern Hemisphere } & \multicolumn{2}{|c|}{ Southern Hemisphere } \\
\hline & $\begin{array}{c}\text { Fission Yields } \\
\text { (MT) }\end{array}$ & $\begin{array}{c}{ }^{90} \mathrm{Sr} \text { Deposition } \\
\text { (PBq) }\end{array}$ & $\begin{array}{c}\text { Fission Yields } \\
\text { (MT) }\end{array}$ & $\begin{array}{c}{ }^{90} \mathrm{Sr} \text { Deposition } \\
\text { (PBq) }\end{array}$ \\
\hline 1958 & 29.0 & 23.3 & 0.0 & 9.6 \\
\hline 1959 & 0.0 & 38.9 & 0.0 & 6.7 \\
\hline 1960 & 0.1 & 9.6 & 0.0 & 6.3 \\
\hline 1961 & 25.0 & 13.0 & 0.0 & 6.3 \\
\hline 1962 & 77.0 & 53.3 & 0.0 & 9.6 \\
\hline 1963 & 0.0 & 96.9 & 0.0 & 11.5 \\
\hline 1964 & 0.0 & 61.4 & 0.0 & 15.5 \\
\hline 1965 & 0.0 & 28.5 & 0.0 & 13.3 \\
\hline 1966 & 0.6 & 12.2 & 0.7 & 7.8 \\
\hline 1967 & 1.7 & 6.3 & 0.2 & 4.1 \\
\hline 1968 & 1.2 & 7.4 & 4.1 & 3.7 \\
\hline 1969 & 2.0 & 5.6 & 0.0 & 5.2 \\
\hline 1970 & 2.0 & 7.8 & 2.6 & 4.8 \\
\hline 1971 & 0.0 & 7.0 & 2.0 & 5.6 \\
\hline 1972 & 0.1 & 3.2 & 0.1 & 3.6 \\
\hline 1973 & 1.6 & 1.2 & 0.1 & 1.2 \\
\hline 1974 & 0.5 & 4.5 & 1.1 & 1.4 \\
\hline 1975 & 0.0 & 2.2 & 0.0 & 1.3 \\
\hline 1976 & 2.4 & 1.0 & 0.0 & 0.8 \\
\hline 1977 & 0.0 & 3.0 & 0.0 & 0.8 \\
\hline 1978 & 0.0 & 3.7 & 0.0 & 0.7 \\
\hline 1979 & 0.0 & 1.1 & 0.0 & 0.4 \\
\hline 1980 & 0.5 & 0.6 & 0.0 & 0.3 \\
\hline 1981 & 0.0 & 1.6 & 0.0 & 0.3 \\
\hline 1982 & 0.0 & 0.5 & 0.0 & 0.2 \\
\hline 1983 & 0.0 & 0.3 & 0.0 & 0.2 \\
\hline 1984 & 0.0 & 0.3 & 0.0 & 0.1 \\
\hline 1985 & 0.0 & 0.1 & 0.0 & 0.1 \\
\hline 1986 & 0.0 & 1.5 & 0.0 & 0.2 \\
\hline 1987 & 0.0 & 0.1 & 0.0 & 0.2 \\
\hline 1988 & 0.0 & 0.1 & 0.0 & 0.1 \\
\hline 1989 & 0.0 & 0.1 & 0.0 & 0.2 \\
\hline 1990 & 0.0 & 0.0 & 0.0 & 0.1 \\
\hline
\end{tabular}




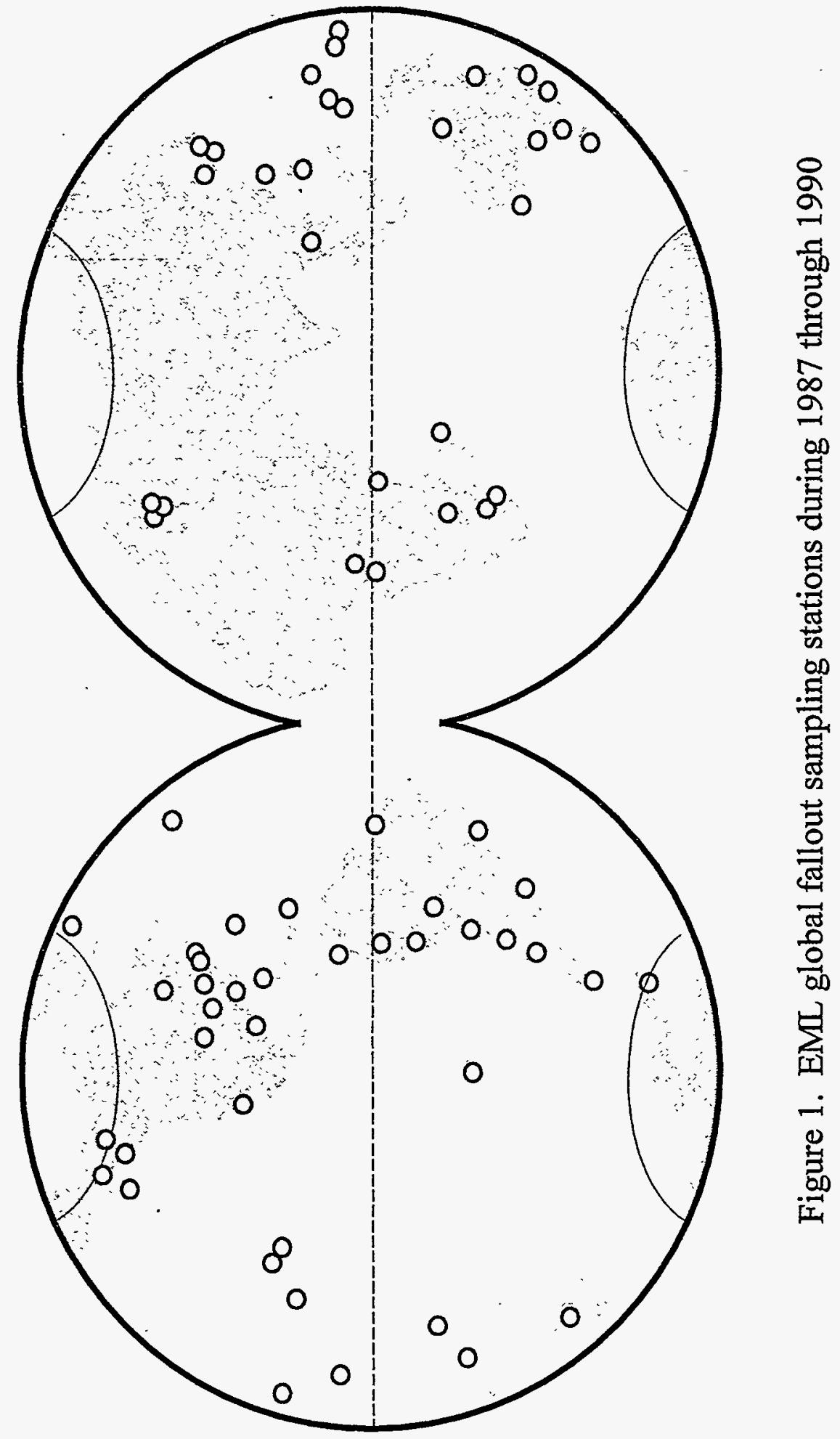




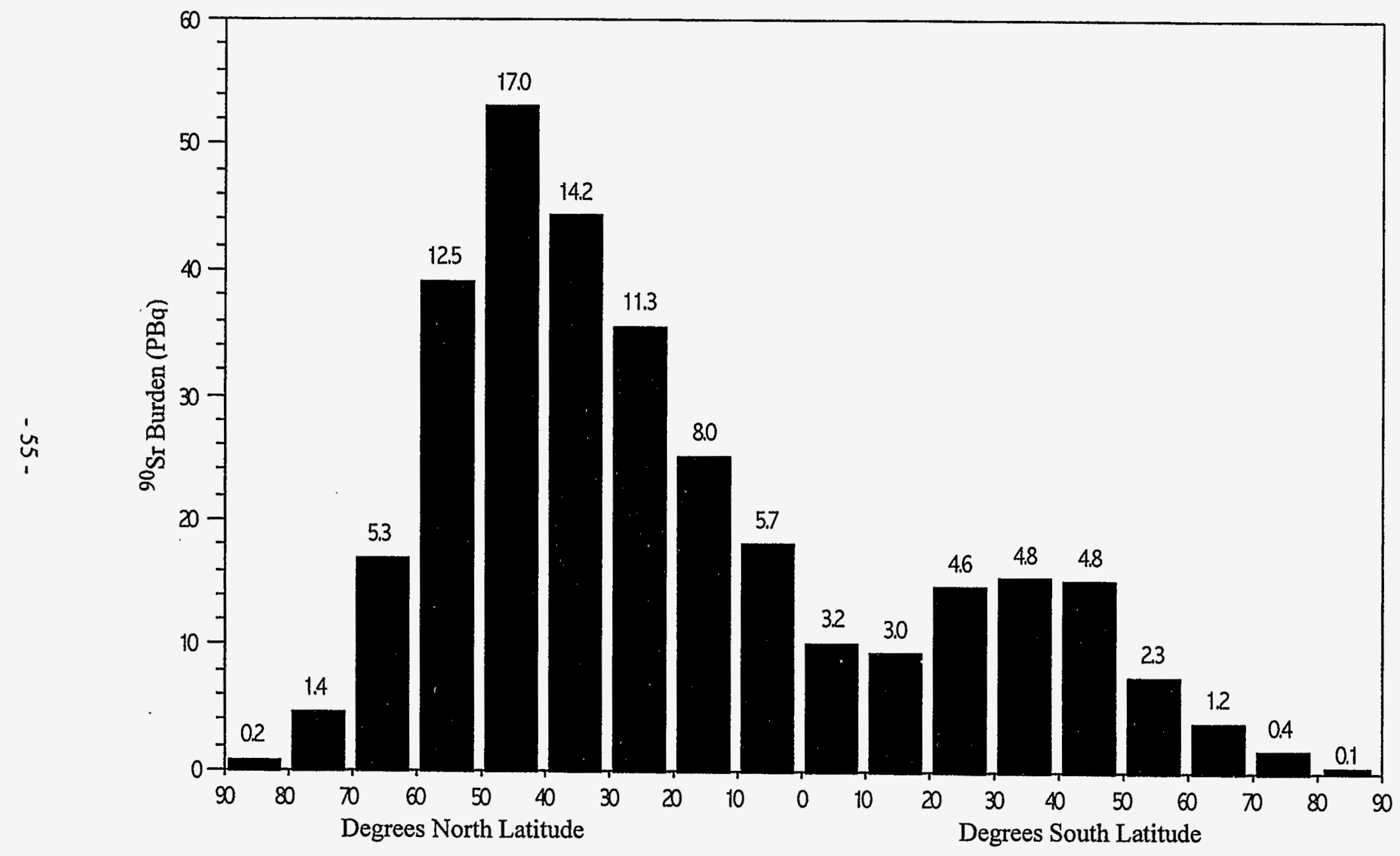

Figure 2. Latitudinal distribution of global ${ }^{90} \mathrm{Sr}$ burden at the end of 1990 

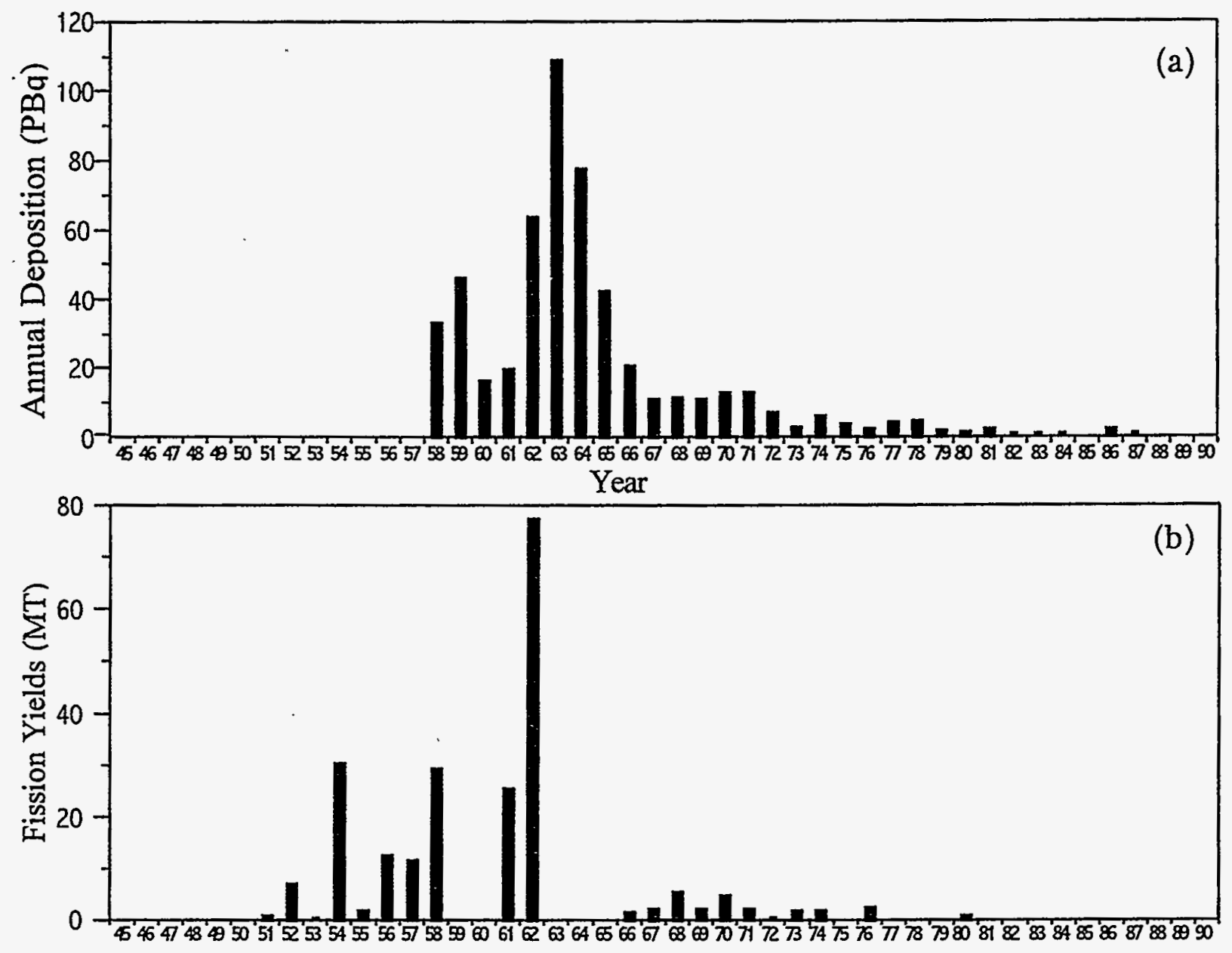

Year

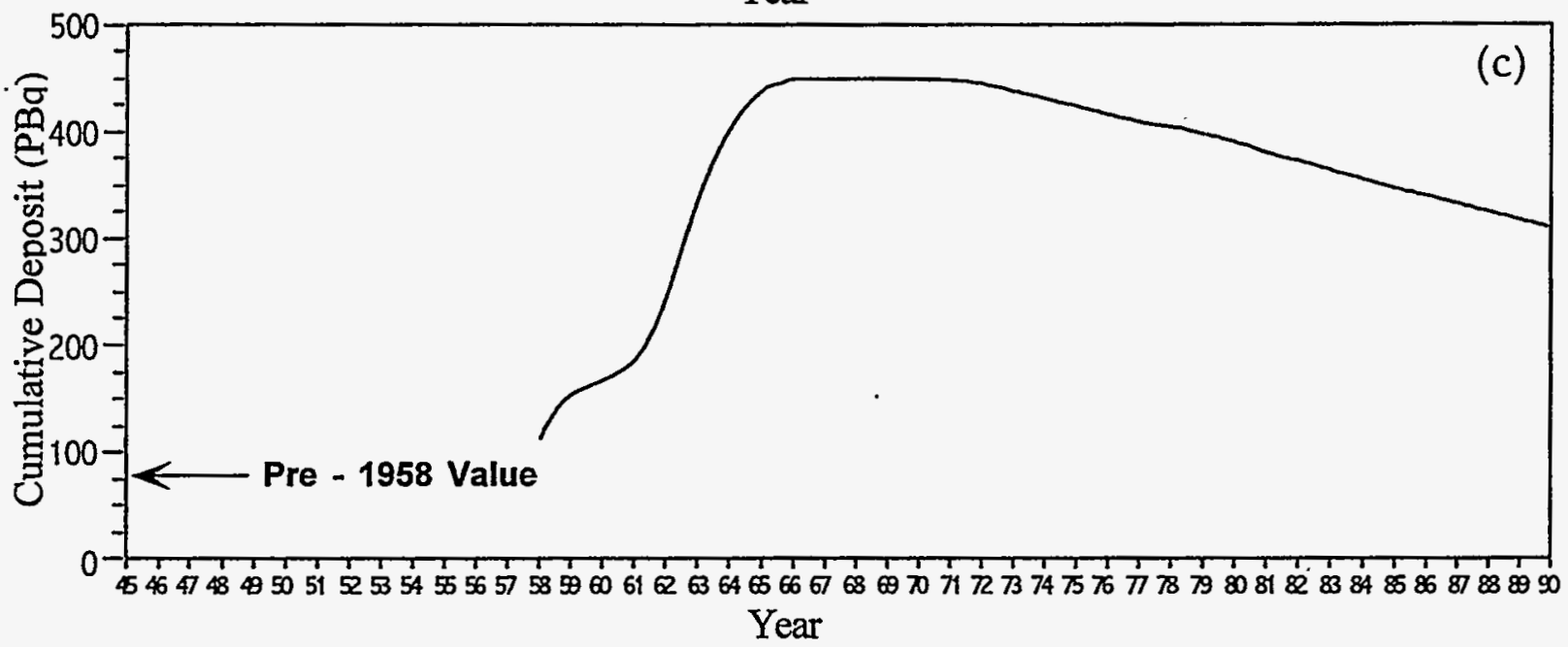

Figure 3. Temporal patterns of atmospheric weapons testing and ${ }^{90} \mathrm{Sr}$ deposition:

(a) annual global ${ }^{90} \mathrm{Sr}$ deposition from 1958 to 1990

(b) annual fission yield from atmospheric weapons testing

(c) cumulative global deposit of ${ }^{90} \mathrm{Sr}$ from 1958 to 1990 



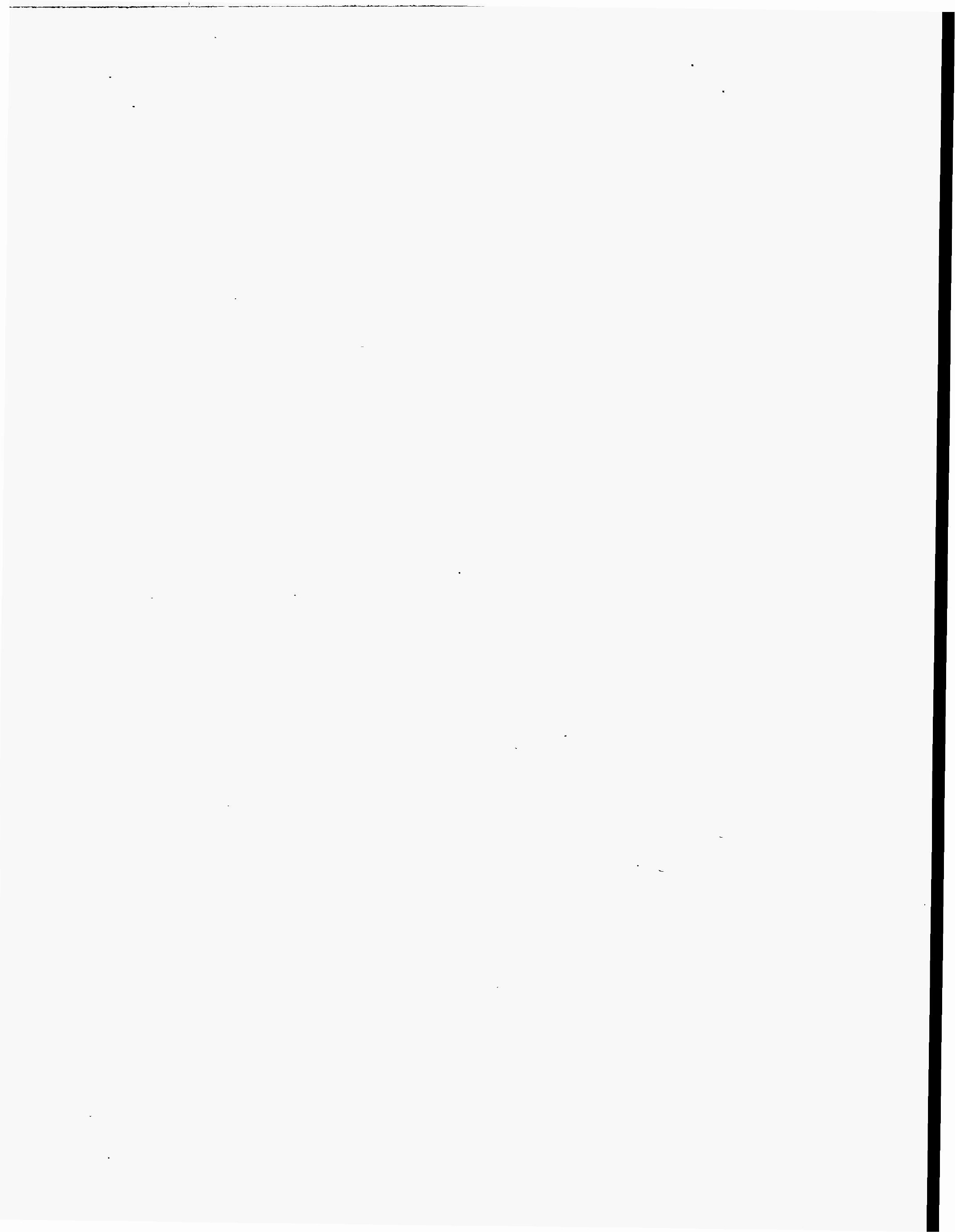

